\title{
Lichens of Aisen, Southern Chile
}

\section{Líquenes de Aisén, sur de Chile}

\author{
Wanda Quilhot, Mauricio Cuellar, Rodrigo Díaz, Francisco Riquelme \& Cecilia Rubio \\ Herbario de Líquenes UV, Departamento de Química y Recursos Naturales, Facultad de Farmacia, Universidad de Valparaíso, \\ Casilla 5001, Valparaíso, Chile. \\ wanda.quilhot@uv.cl
}

\begin{abstract}
The lichen mycobiota of Aisen (southern Chile) comprises 319 taxa in 87 genera. All of the species of Menegazzia and Protousnea, previously recorded in Chile, are present in this region. The diversity of biomes, from temperate rainforests - particularly in oceanic zones- to steppe areas, offers an enormous number of macro and microhabitats favorable for lichens. The highest lichen diversity, 56 \%, was recorded in an undisturbed locality in Laguna San Rafael National Park. Lichen species diversity is higher in oceanic temperate rainforests than in steppe areas, where the majority of Antarctic lichens $(23 \%)$ are registered. Levels of endemism are rather high $(26 \%)$ and are due mainly to species of the genera Protousnea, Pseudocyphellaria, Menegazzia, Cladonia, Sticta, Nephroma. Other biogeographical elements in the región's lichen mycobiota are: cosmopolitan (16\%), austral (16\%) and bipolar (13\%). Lichen diversity in Aisen represents about $20 \%$ of the known lichen mycobiota of Chile.
\end{abstract}

KEYWORDS: Lichen diversity, endemism, steppe areas, biogeography.

\section{RESUMEN}

La micobiota liquénica de la Región de Aisén incluye 319 especies en 87 géneros; el número total de especies de los géneros Menegazzia y Protousnea registrados en Chile se encuentran en esta región. La diversidad de biomas, desde bosques templado-lluviosos, particularmente en zonas oceánicas, a áreas estepáricas, ofrece una variedad de macro y microhabitats favorables para los líquenes. La mayor diversidad liquénica (56 \%) se registró en un área silvestre no intervenida en el Parque Nacional Laguna San Rafael. La diversidad específica es más elevada en bosques templado-lluviosos que en zonas estepáricas, en estas últimas se registró la mayoría de los líquenes antárticos (23.0\%). El endemismo es más bien elevado (26.0 \%); numerosas especies de los géneros Protousnea, Pseudocyphellaria, Menegazzia, Cladonia, Sticta, Nephroma son endémicas del sur de América del Sur. Las especies cosmopolitas (16\%), australes (16\%) y bipolares (13\%) son los elementos biogeográficos más representativos. La diversidad liquénica de Aisen corresponde al $20 \%$ de la flora liquénica de Chile.

Palabras Clave: Diversidad liquénica, endemismo, áreas estepáricas, biogeografía.

\section{INTRODUCTION}

Aisen, XI Region, is located in the south of Chile $\left(44^{\circ} 15^{\prime}\right.$ and $\left.51^{\circ} 15^{\prime} \mathrm{S}, 71^{\circ} 45^{\prime} \mathrm{W}\right)$. Due to its complexity of topography and climate (Daniels \& Veblen 2000, Kitzberger \& Veblen $2000)$ the region is characterized by several biomes with a considerable number of macro and microhabitats available for colonization by lichens. Climate ranges from oceanic to arid steppe favouring the development of lichens in terms of both diversity and biomass. Aisen is one of the least known regions in Chile due to the difficulties in exploring some of its distant places.

Major contributions to present knowledge of lichens in
Aisen were made by Galloway (1992a, 1992b, 1994, 1996, 2002), Galloway \& Jørgensen (1995), Bjerke (2001, 2005), Bjerke \& Elvebakk (2001), Bjerke et al. (2003a), Wedin (1995, 2002), Jørgensen \& Wedin (1999), Stenroos (1995), Elvebakk (2007), Elvebakk \& Moberg (2002), Elvebakk \& Bjerke (2005), Elvebakk et al. (2007, 2010), Krog (1976) and Quilhot et al. (2002a,b).

The lichen mycobiota of Aisen is of particular importance because it occupies a transitional position between Antarctica and Magellanic tundra, to the south, and the wetter Valdivian rainforest of the north.

Here we report data from on-going studies that contribute to better undestand of the lichen flora of Aisen, 
through a more accurate assessment of distributional data and biogeographical affinities.

\section{METHODS}

Compilation of the lichen mycobiota from Aisen follows the methods outlined: published lichen records from Aisen; fieldwork funded by the Dirección de Investigación of Universidad de Valparaiso, project Darwin's Initiative for the Survival of the Species (1997), funded by the United Kingdom; project Biodiversidad de Aisen (2000-2004), funded by the European Community. Fieldwork and logistical support was provided by CONAF XI Región and Raleigh International from the United Kingdom.

Identification of the species was undertaken in collaboration with lichenologists David Galloway from Landcare Research Ltd., New Zealand; Jarle Werner Bjerke and Arve Elvebakk, from the University of Trømso, Norway, and Bernard Goffinet from the University of Alberta, Canada.

The species are arranged alphabetically and include data on lichen habitat, records in Aisen, known distribution in Chile and world distribution. The list of taxa includes all lichen material determined at species level. Nomenclature follows Galloway \& Quilhot (1998), and more recent taxonomic treatments. Lichen material collected and analized is housed in the Herbario de Líquenes (UV), Universidad de Valparaíso.
STUDY SITES

Liquen inventories were conducted in the following sites (Fig. 1).

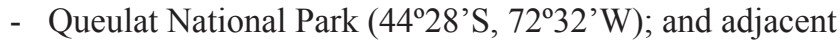
localities: Las Juntas, Puyuhuapi and Río Cisnes.

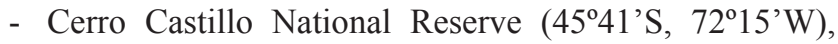
Villa Cerro Castillo, Coyhaique (4532' S; 7241' W), Río Simpson National Reserve, Puerto Aisen, lago Riesco and Villa Mañihuales $100 \mathrm{~km} \mathrm{~N}$ of Coyhaique.

- Jeinimeni National Reserve (46 50 'S, 72 $00^{\prime}$ W), at altitudes between 500 and $1200 \mathrm{~m}$ and adjacent localities: Chile Chico, Fachinal on the riverside to Lago General Carrera, Puerto Bertrand, Valle Exploradores $35 \mathrm{~km}$ from Puerto Tranquilo and Bahía Murta (46 $\left.27^{\circ} \mathrm{S} ; 7^{\circ} 14^{\prime} \mathrm{W}\right)$.

- Lago Cochrane National Reserve: Tamango (47³0' S, $72^{\circ} 30^{\prime} \mathrm{W}$ ) at altitude between 180 and $1400 \mathrm{~m}$, and adjacent localities: San Lorenzo and Vagabundo.

- Laguna San Rafael National Park: Puntilla Los Cisnes

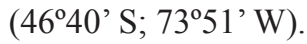

- Caleta Tortel $\left(47^{\circ} 41^{\prime} \mathrm{S}, 73^{\circ} 00^{\prime} \mathrm{W}\right)$ and adjacent localities: on the road to Puerto Yungay, Fiordo Michel, $20 \mathrm{~km} \mathrm{~S}$ on the road to Villa O'Higgins.

- Katalalixar National Reserve (47²8' S, 72057' W). Lichens in this site were collected by Dr. Jorge Cuvertino.

The Darwin Project focussed intensive collecting in Laguna San Rafael, in Puntilla Los Cisnes (Quilhot et al. 2002 a,b,c), while the Project Biodiversidad de Aisen provided the opportunity to study lichens of previously unexplored areas as National Reserves Lago Cochrane (Tamango) and Jeinimeni.

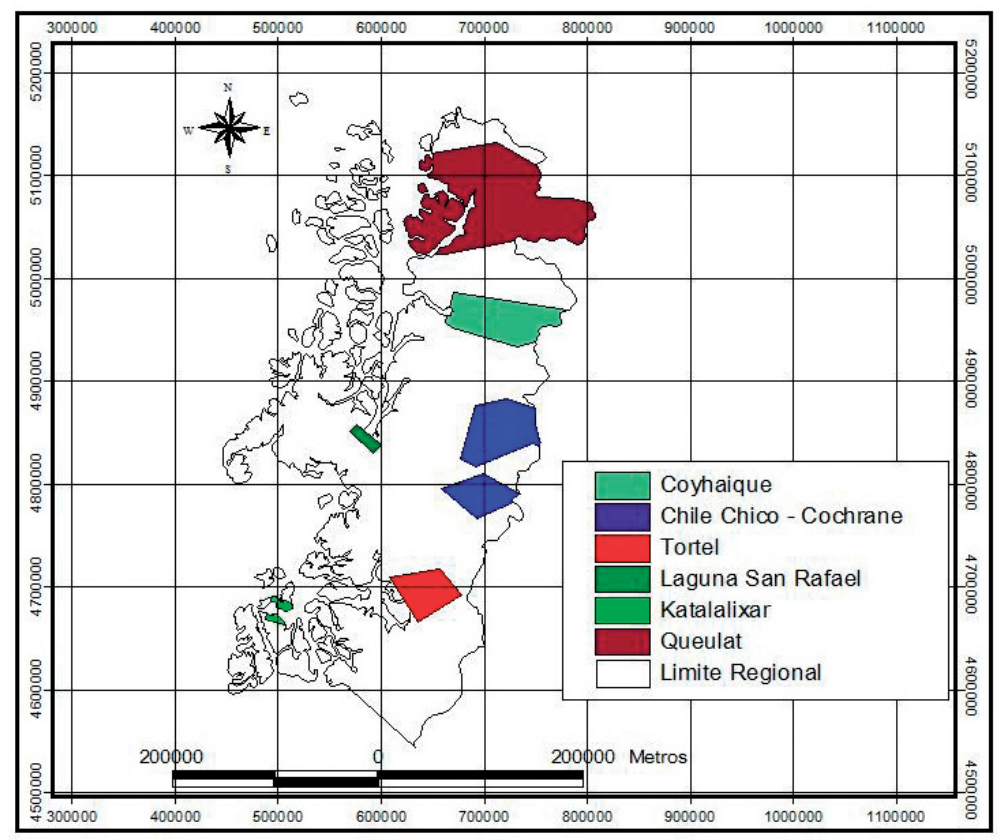

Figure 1. Distribution of the collecting sites in Aisen Region. UTM coordinates.

Figura 1. Distribución de los sitios de recolección en la región de Aisén. Coordenadas UTM. 


\section{RESULTS AND DISCUSSION}

A total of 321 taxa of lichens are here recorded in Aisen. All the species recorded to Chile belonging to genera Menegazzia and Protousnea are present in Aisen. Similarly, the majority known species of Bunodophoron, Cladonia, Leptogium, Placopsis, Pseudocyphellaria and Sticta were registered for the region. Foliicolous lichens, such as Fellhanera dominicana, Calopladia fusca, Coccocarpia dominguensis, C. erythrxoylii, C. palmicola, Mazosia phyllosema and Tapellaria epiphylla were also found in this region. The lichens recorded in Aisen represent about $20 \%$ of the total lichen mycobiota known from Chile.

Lichen diversity is higher in temperate rainforests as is observed by the number of species recorded in Laguna San Rafael, Valle Exploradores or in Queulat National Park.

The highest diversity per locality was observed in Puntilla Los Cisnes, a small area located at sea level in the vicinity of the glacier in Laguna San Rafael, 178 taxa are recorded, representing about $56 \%$ of the total lichen diversity of Aisen. The lichen mycobiota has strong affinities with those of Valdivian rainforest and is exceptionally rich in lichens; examples: the total number of the species of the genera Menegazzia and continental species of Sticta are present in this area, while Pseudocyphellaria is represented with 42 species (out of 54 known to Chile).

On the other hand, the biomass of Coccotrema coccophorus growing on Embothrium coccineum J.R. Forst. et G. Forst. is really quite exceptional. Origin and maintenance of this high local species diversity may be explained as a result of high rainfall and frequent cloudy days, a climate regime particularly suitable for the growth of lichens (Galloway 1992a). Also, the strong fires that occurred in the middle of the last century did not affect the vicinity of the glacier where Puntilla Los Cisnes is located and, finally, because the intensity of lichen collecting and inventories in the area. It is also worth to mention that Laguna San Rafael is one of the few localities in coastal ecosystems in Aisen where the original lichen diversity can still be seen; obviously lichen colonization is new in areas affected by fires.

Lichen diversity is lower in steppe and semi-steppe areas than it is in more humid rainforests; the number of the species recorded represents about $47 \%$ of the lichen flora in Aisen. In Tamango, located in a semi-steppe area, and where lichen collecting was conducted at altitudes between 180 and 1400 m, 187 taxa were recorded. Protousnea, a lichen genus known only from Chile and Argentina (Krog 1976, Calvelo et al. 2003, 2005), is dominat in these biomes. All of the species in the genus are found in steppe areas at elevation from $250 \mathrm{~m}$ to $1400 \mathrm{~m}$. A very high biomass was seen in Tamango, particularly of $P$. malacea, and $P$ dusenii in Jeinimeni. Species of this genus are completely absent from coastal ecosystems in Aisen.
Climate and other environmental features of seppe areas seem to be ideal for the growth and development of species other than Protousnea, e.g. with Menegazzia: M. globulifera is most frequent in relatively dry and open forests dominated by Nothofagus pumilio (Poepp. et Endl.) Krasser, at an elevation of 700-1200 m, in Jeinimeni; $M$. chrysogaster and M. kawesqarica are currently found on more shaded habitats in Tamango.

The alpine lichen flora of steppe areas has a significant number of Antarctic species. 76 taxa (about $23 \%$ ) were recorded at an elevation of 300 to $1400 \mathrm{~m}$. Lecanora, Parmelia, Rhizoplaca, Peltigera, Physconia, Rhizocarpon, Toninia, Umbilicaria, Usnea, are some of the Antarctic genera recorded in Aisen. It is proposed that this observed lichen disjunction is because the exceptional dispersal capabilities in very similar habitats ecologically (Högberg et al. 2002); an additional explanation is that ecologically similar areas that are now widely separated from each other are often remnants of formerly coherent vegetation belts (Printzen et al. 2003). Many of the Antarctic lichens found in Aisen were recorded in alpine zones in North and Central Chile (Quilhot et al. 2007). For example, Physconia muscigena, Rhizoplaca melanophthalma, Toninia bullata were recorded in the Altiplano, between Putre and Chucuyo at an altitude of 3500-4500 m (Galloway 1998); while Rhizoplaca aspidophora, Umbilicaria decussata in Portillo at $2500-2800 \mathrm{~m}$, and $R$. aspidophora, $R$. melanophthalma and Toninia bullata in Laguna del Maule at $2700 \mathrm{~m}$ elevation. Ecological conditions in these sites are very similar to steppe areas in Aisen.

The lichen mycobiota of the Juan Fernández Archipiélago is well represented in Aisen, particularly in temperate rainforests, representing $18 \%$ of the total lichen flora of Aisen. Pseudocyphellaria dissimilis, endemic to Juan Fernández (Galloway 1992b), was collected in Katalalixar and on the road between Cochrane and Villa O'Higgins.

From a biogeographical persective, lichens of Aisen are of considerable interest in the lichenic flora of Chile. Endemism is on the order of $26 \%$; the genus Protousnea, numerous species of Pseudocyphellaria, Menegazzia, Sticta, Nephroma, Cladonia, Placopsis are endemic to southern South America; Rhizoplaca aspidophora, considered as an endemic element in Antarctica (Øvstedal \& Lewis Smith 2001), was recorded in Jeinimeni and Tamango at 850 and $1100 \mathrm{~m}$, respectively. Bipolar elements, $13 \%$, are characteristics of the steppe area in alpine habitats. Austral elements, about $16 \%$, are present in rainforests. Cosmopolitan elements represent $16 \%$. Other biogeographical elements are not included because of their low numbers in Aisen.

In conclusion, the lichen mycobiota of Aisen recorded below is still incompletely known, because of inaccessibility, complex topography and extent of the region. One of the keys to increasing knowledge of lichen diversity is to conduct intensive collections in each locality, as has been 
shown for Laguna San Rafael, Tamango and Jeinimeni. In addition, over the last few years, Aisen has been transformed in a wide private area, imposing restrictions to the access, including temperate rainforests. Thus our knowledge of lichen diversity in Aisen must remain incomplete.

\section{RECORDED TAXA}

Alectoria ochroleuca (Hoffm.) A. Massal.

HABITAT ECOLOGY: on bark of large trees particularly in alpine habitats from sea level to $1100 \mathrm{~m}$. RECORDS IN AISEN: Tamango and Laguna San Rafael. Distribution IN Chile: Llanquihue to Isla Navarino. GLOBAL Distribution: circumpolar. (Brodo \& Hawksworth1977; Redón 1974; Redón \& Quilhot 1977).

Amandinea punctata (Hoffm.) Coppins \& Scheid. Habitat ecology: on rocks in open sites. Records in Aisen: Laguna Tamanguito (Tamango) $1100 \mathrm{~m}$ altitude. Distribution in Chile: Copiapó to Magallanes and Antarctic Territory. GLOBAL DISTRIBUTION: bipolar.

(Øvstedal \& Lewis Smith 2001; Scheidegger 1993).

\section{Anzia afromontana R. Sant.}

Habitat ecology: on bark of large trees in humid forests; from sea level to $1100 \mathrm{~m}$ altitude. ReCORDS IN Aisen: Laguna San Rafael. Distribution IN Chile: Llanquihue to Magallanes. Global Distribution: known in South America and Africa.

(Adler \& Calvelo 1996a; Redón 1974).

Bacidina pallidocarnea (Müll. Arg.) Vězda

HABitat ECOLOGY: on living leaves of trees and shrubs in Valdivian rainforest. ReCords IN Aisen: Laguna San Rafael. Distribution in Chile: Valdivia to Aisen. Global DISTRIBUTION: pantropical.

(Lucking et al. 2003).

Bryoria chalybeiformis (L.) Brodo \& Hawksw.

HABITAT ECOLOGY: on rocks in steppe areas, usually montane to alpine, rare in maritime regions. RECORDS IN AISEN: Jeinimeni, Tamango and San Lorenzo. Distribution in Chile: Aisen to Isla Navarino and Antarctic Territory. Global Distribution: bipolar.

(Øvstedal \& Lewis Smith 2001; Redón 1985; Ryan 2002a).

\section{Bunodophoron australe (Laurer) A. Massal.}

HABitat ECOLOGY: a common and widespread species in cool temperate rainforests. RECORDS IN AISEN: Lago Las Torres, Puerto Aisen, Valle Exploradores, Laguna San Rafael and Katalalixar. Distribution in Chile: Valdivia to Magallanes. Global Distribution: the species is known from Argentina, Chile, New Zealand, Tasmania, New Caledonia and Hawaii.

(Elix \& McCarthy 1998; Wedin 1995).
Bunodophoron dodgei (Ohlsson) Wedin

Habitat ECOlOGY: on trunks in large trees in cool temperate rainforests. Records in Aisen: Lago Las Torres, Puerto Aisen, Lago Riesco, Laguna San Rafael, on the road side to Puerto Yungay. Distribution in Chile: Malleco Province to Magallanes. Global distribution: endemic to southern South America.

(Wedin 1995).

Bunodophoron imshaugii (Ohlsson) Wedin

HABITAT ECOLOGY: on trunks in large trees in cool temperate rainforests. RECORDS IN AISEN: Valle Exploradores, Laguna San Rafael, Puerto Ballena and Katalalixar. Distribution IN Chile: Nahuelbuta National Park to Magallanes. Global DISTRIBUTION: the species is widespread in the Southern Hemisphere, and is known from Chile, New Caledonia, New Zealand and Tasmania.

(Elix \& McCarthy 1998; Wedin 1995).

\section{Bunodophoron insigne (Laurer) Wedin}

Habitat eCology: on trunks in large trees in Valdivian rainforest. Records in Aisen: Lago Las Torres, Puerto Aisen, Laguna San Rafael, on the road to Puerto Yungay and Katalalixar. Distribution in Chile: from Nahuelbuta National Park to Magallanes. Global Distribution: the species is known from Argentina, Chile, New Zealand, South Australia, and the Solomon Islands.

(Elix \& McCarthy 1998; Wedin 1995).

Bunodophoron patagonicum (C.W. Dodge) Wedin HABITAT ECOlOGY: on trunks in large trees in Valdivian rainforest. Records in Aisen: Puerto Aisen, Lago Riesco, and on the road to Puerto Portales. Distribution in Chile: Juan Fernández Archipiélago, and from Malleco Province to Magallanes. Global Distribution: austral.

(Wedin 1995).

Bunodophoron ramuliferum (I.M. Lamb) Wedin

HABITAT ECOLOGY: on trunks in large trees in cool temperate rainforests. ReCords in Aisen: Puerto Aisen and Laguna San Rafael. Distribution in Chile: Juan Fernández Archipiélago, and from Malleco Province to Magallanes. GLOBAL DISTRIBUTION: the species is very widespread, occurring in southernmost South America, Argentina, Chile, New Zealand, Australia and New Caledonia. (Elix \& McCarthy 1998; Wedin 1995).

Bunodophoron scrobiculatum (C. Bab.) Wedin HABITAT ECOLOGY: on trunks in large trees in Valdivian rainforest. Records in Aisen: Puerto Aisen. Distribution IN Chile: Juan Fernández Archipiélago, and from Malleco Province to Magallanes. Global distribution: the species is widely distributed in the Southern Hemisphere, occurring in the southern South America, New Zealand and Tasmania. 
(Wedin 1995).

Bunodophoron tibellii (Wedin) Wedin

HABITAT ECOlOGY: on trunks in large trees in Valdivian rainforest. Records in Aisen: Laguna San Rafael. Distribution in Chile: Aisen. Global Distribution: Australia, New Zealand and Chile. (Wedin 1995, Wedin pers. comm.).

Bunodophoron whakapapaense (Wedin) Wedin HABITAT ECOLOGY: an epiphyte on mature trunks of Nothofagus dombeyi (Mirb.) Oerst. and other tree species in Valdivian rainforest. Records in Aisen: Lago Las Torres, Puerto Aisen, Laguna Los Palos and Lago Riesco. Distribution in Chile: Aisen. Global Distribution: austral.

(Wedin 1995).

Caloplaca regalis (Vain.) Zahlbr.

Habitat ecology: on rocks in open sites. Records in Aisen: Tamango. Distribution in Chile: Aisen to Magallanes and Antarctic Territory. Global Distribution: the species is known from southern South America and Antarctica.

(Øvstedal \& Lewis Smith 2001).

Caloplaca sublobulata (Nyl.) Zahlbr.

Habitat eCOlogy: on rocks in open sites. Records in Aisen: Laguna San Rafael. Distribution in Chile: Aisen to Isla Navarino and Antarctic Territory. Global DISTRIBUtion: austral.

(Galloway 2007; Øvstedal \& Lewis Smith 2001; Redón \& Quilhot 1977).

\section{Calopladia fusca (Müll. Arg.) Vězda}

Habitat ECOlOgy: on leaves on trees and shrubs. ReCORDS IN Aisen: Laguna San Rafael. Distribution in Chile: Aisen to Magallanes. GLOBAL DISTRIBUTION: pantropical.

(Lücking 1992).

Calycidium polycarpum (Colenso) Wedin

HABITAT ECOLOGY: an epiphyte of trees and shrubs, sometimes over mosses, in temperate rainforests, from sea level to 935 m elevation. Records in Aisen: $13 \mathrm{~km} \mathrm{~N}$ of Puerto Aisen. Distribution in Chile: Choshuenco (X Región) to Aisen. Global Distribution: the species is known from Argentina, Chile, New Zealand and Tasmania.

(Wedin 2002).

Cetraria aculeata (Schreb.) Fr.

Habitat eCOlogy: on rocks and mosses in steppe areas. RECORDS In Aisen: Tamango (1000 m elevation) and Tortel. Distribution in Chile: Llanquihue to Isla Navarino and Antarctic Territory. GlobAL DistriBution: bipolar-alpine. (Øvstedal \& Lewis Smith 2001; Redón \& Quilhot 1977).
Chrysothrix pavonii (Fr.) J.R. Laundon

HABITAT ECOlOGY: on tree trunks, on rocks and rotten wood in open sites. Records In Aisen: Coyhaique Alto and Laguna Verde (Jeinimeni). Distribution in Chile: Punta Patache (Iquique) to Magallanes. Global Distribution: cosmopolitan.

(Laundon 1981; Muñoz-Schick 2001).

\section{Cladia aggregata (Sw.) Nyl.}

HABITAT ECOLOGY: terricolous in a variety of habitats from moist Nothofagus forests to bogs, heaths and grassland at all altitudes. ReCORDS IN Aisen: Tamango, Laguna San Rafael and Katalalixar. Distribution IN ChiLE: Juan Fernández Archipiélago, and from Nuble Province to Tierra del Fuego and Antarctic Territory. Global Distribution: paleotropical. (Øvstedal \& Lewis Smith 2001; Stenroos 1995).

Cladia schizopora (Nyl.) Nyl.

HABITAT ECOLOGY: on rotten trunks and stumps in forests and open sites. Records IN Aisen: Laguna San Rafael. Distribution in Chile: Valdivia to Aisen. Global DISTRIBUTION: austral.

(Stenroos 1995).

Cladonia arbuscula (Wallr.) Flot.

Habitat ECOlOGY: on soil in open sites, sometimes in Nothofagus forests. ReCORds in Aisen: Puerto Aisen. Distribution in Chile: Malleco Province to Tierra del Fuego and Antarctic Territory. GlobAl DISTRIBUTION: bipolar.

(Øvstedal \& Lewis Smith 2001; Stenroos 1995).

Cladonia bacilliformis (Nyl.) Glück

Habitat ecology: on rotten wood, rare in Nothofagus antarctica (G. Forst) Oerst. and N. pumilio forests. RECORDS IN Aisen: Coyhaique. Distribution en Chile: Aisen to Tierra del Fuego and Antarctic Territory. Global Distribution: bipolar.

(Øvstedal \& Lewis Smith 2001; Stenroos 1995).

Cladonia bellidiflora (Ach.) Schaer.

HABITAT ECOLOGY: in bogs and peaty spots in Nothofagus forests, more frequent at higher elevations. RECORDS IN Aisen: Puerto Aisen. Distribution in Chile: Aisen to Tierra del Fuego and Antarctic Territory. Global Distribution: bipolar.

(Øvstedal \& Lewis Smith 2001; Stenroos 1995).

Cladonia borealis S. Stenroos

HABITAT ECOLOGY: in forest margins, bogs, sandy beaches, rocks outcrops. ReCORDS In Aisen: Coyhaique. Distribution IN Chile: Osorno to Tierra del Fuego and Antarctic Territory. Global Distribution: bipolar.

(Øvstedal \& Lewis Smith 2001; Stenroos 1995). 
Cladonia cariosa (Ach.) Spreng.

HABitat ECOlOGY: on bare, sandy soil on banks, heath scrub on calcareous cliffs. RECORDS IN AISEN: Coyhaique, Tamango and Tortel. Distribution in Chile: Palena to Tierra del Fuego. Global DistRibution: bipolar.

(Stenroos 1995).

Cladonia carneola (Fr.) Fr.

HaBitat ECOlogy: on rotten wood and humous soil, mainly in Nothofagus forests, rarely in open scrub, cushion heaths, steppe and bogs. ReCORdS In Aisen: Coyhaique and Tamango. Distribution in Chile: from Osorno to Tierra del Fuego and Antarctic Territory. Global DISTRIBUTION: bipolar.

(Øvstedal \& Lewis Smith 2001; Stenroos 1995).

Cladonia chlorophaea (Flörke ex Sommerf.) Spreng. HABITAT ECOlOgY: on soil and rotten wood in drier habitats like steppe, sandy road side and scrub; also in open forests habitats. Records in Aisen: Coyhaique, Tamango, Laguna San Rafael and Tortel. Distribution in Chile: Limarí, Juan Fernández Archipiélago; and from Valparaíso to Magallanes and Antartic Territory. Global Distribution: cosmopolitan. (Øvstedal \& Lewis Smith 2001; Stenroos 1995).

\section{Cladonia confragosa S. Stenroos}

HABITAT ECOLOGY: primarily on soil, also found on rotten wood in temperate rainsforests. RECORDS IN AISEN: Carretera Austral between Cochrane and Villa O'Higgins. Distribution in Chile: Curicó to Tierra del Fuego. Global distribution: endemic to southern South America. (Ahti 2000; UACH-UDEC 2007, 2008).

\section{Cladonia corniculata Ahti \& Kashiw.}

HABITAT ECOLOGY: in open habitats like woodland, scrub, trailsides, forest margins and heaths, occasionally in Nothofagus forests. ReCORDS IN Aisen: Coyhaique. Distribution in Chile: Valparaíso to Tierra del Fuego. GLOBAL DISTRIBUTION: austral.

(Stenroos 1995).

Cladonia didyma (Fée) Vain.

Habitat ecology: on rotten wood in forests and roadside scrub. Records in Aisen: Laguna San Rafael. Distribution IN ChILE: Limarí, Juan Fernández Archipiélago; and from Malleco Province to Magallanes. Global Distribution: pantropical.

(Stenroos 1995).

Cladonia farinacea Vain.

HabitAT ECOlOGY: on soil in Nothofagus forests, more rarely in open habitats and roadside scrub. RECORDS IN AIsEN: Puerto Aisen and Laguna San Rafael. Distribution in Chile: Limarí to Tierra del Fuego and Antarctic Territory. Global DISTRIBUTION: bipolar.
(Øvstedal \& Lewis Smith 2001; Stenroos 1995).

Cladonia fimbriata (L.) Fr.

HABITAT ECOLOGY: on rotten wood and soil in a wide variety of habitats, from oceanic forests to steppes. RECORDS IN Aisen: Coyhaique and Laguna San Rafael. Distribution IN Chile: Limarí to Magallanes and Antarctic Territory. Global DISTRIBUTION: bipolar.

(Øvstedal \& Lewis Smith 2001; Stenroos 1995).

Cladonia furcata (Huds.) Schrad.

HABITAT ECOLOGY: on soil and rotten wood in open habitats. ReCordS in Aisen: Tamango and Laguna San Rafael. Distribution in Chile: Valparaíso to Magallanes. Global Distribution: cosmopolitan.

(Stenroos 1995).

Cladonia gracilis (L.) Willd. spp. elongata (Wulf.) Vain. HABITAT ECOLOGY: on soil, plant debris and peats; common in open habitats, particularly in bogs. ReCORDS IN AISEN: Tamango, Laguna San Rafael and Tortel. Distribution IN CHILE: Juan Fernández Archipiélago, and from Osorno to Tierra del Fuego and Antarctic Territory. Global DISTRIBUTION: bipolar.

(Øvstedal \& Lewis Smith 2001; Stenroos 1995).

Cladonia gracilis (L.) Willd. spp. gracilis (L.).Willd.

HABITAT ECOLOGY: on soil and rocks in open habitats like heaths, felmarks and bogs. ReCords in Aisen: Puerto Aisen and on the roadside to Puerto Yungay. Distribution In Chile: Juan Fernández Archipiélago, and from Valdivia to Tierra del Fuego and Antartic Territory. Global Distribution: bipolar.

(Øvstedal \& Lewis Smith 2001; Stenroos 1995).

Cladonia gracilis (L.) Willd. spp. valdiviensis Ahti

HABITAT ECOLOGY: on soil, sometimes on lava, in roadside scrub and in oceanic Vadivian rainforest. RECORDS IN AisEn: Laguna San Rafael. Distribution in Chile: Juan Fernández Archipiélago, and from Ñuble Province to Magallanes. Global Distribution: endemic to southern South America. (Galloway 1992a; Stenroos 1995).

Cladonia granulosa (Vain.) Ahti

Habitat eCOlOgy: on soil and rotten wood in open rainforests, roadside scrub and rocky slopes. RECORDS IN Aisen: Coyhaique. Distribution in Chile: Juan Fernández Archipiélago, and from Cautín Province to Aisen. GlobAL Distribution: the species is known in South America.

(Stenroos 1995).

Cladonia laevigata Vain.

Habitat ecology: on soil on peatlands and heaths, oceanic. Records in Aisen: Laguna San Rafael. Distribution in 
Chile: Osorno to Tierra del Fuego and Antarctic Territory. Global Distribution: the species is known in southern South America and Tristán de Cunha.

(Øvstedal \& Lewis Smith 2001; Stenroos 1995).

Cladonia lepidophora Ahti \& Kashiw.

HaBitat eCOlogy: on soil and rocks, also found on stumps and roadside scrub. ReCords in Aisen: Tamango and Laguna San Rafael. Distribution IN ChiLE: Juan Fernández Archipiélago, and from Bio-Bio Province to Magallanes and Antarctic Territory. Global Distribution: southern South America and Antarctic Territory.

(Øvstedal \& Lewis Smith 2001; Stenroos 1995).

\section{Cladonia macilenta Hoffm.}

HABitat eCOlOGY: on rotten trunks and stumps, also on soil, in Nothofagus forests, in open woodlands, roadside scrub and steppe. Records in Aisen: Laguna San Rafael. Distribution in Chile: Limarí, Juan Fernández Archipiélago, Malleco Province to Tierra del Fuego. Global Distribution: cosmopolitan.

(Stenroos 1995).

\section{Cladonia mitis Sandst.}

HaBitat eCOlogy: on soil in open habitats like Sphagnum bogs and cushion heaths. Records in Aisen: Puerto Aisen. Distribution in Chile: Arauco Province to Isla Navarino and Antarctic Territory. Global DISTRIBUTION: bipolar. (Øvstedal \& Lewis Smith 2001, Redón \& Quilhot 1977; Stenroos 1995).

Cladonia norvegica Tønsberg \& Holien

Habitat eCOlogy: on rotten logs and stumps, in humid Nothofagus forests. ReCords in Aisen: Laguna San Rafael. Distribution in Chile: Aisen to Magallanes. Global DISTRIBUTION: bipolar.

(Stenroos 1995).

\section{Cladonia ochrochlora Flörke}

HABITAT ECOLOGY: on rotten trunks and stumps, rarely on soil. Records in Aisen: Puerto Aisen and Laguna San Rafael. Distribution in Chile: Limarí, Concepción to Tierra del Fuego. Global Distribution: cosmopolitan.

(Stenroos 1995).

\section{Cladonia phyllophora Hoffm.}

HABitat ECOlOGY: on soil in open sites, on rock outcrops and steppe margins. RECORDS IN Aisen: Carretera Austral between Cochrane and Villa O'Higgins. Distribution IN Chile: Aisen to Magallanes and Antarctic Territory. Global DISTRIBUTION: bipolar.

(Øvstedal \& Lewis Smith 2001; Stenroos 1995; UACHUDEC 2007, 2008).
Cladonia pocillum (Ach.) Grognot

Habitat ecology: on soil and rock outcrops, on rotten wood in open habitats like steppe and trail sides. RECORDS in Aisen: Coyhaique. Distribution in Chile: Valparaíso, Valdivia to Tierra del Fuego and Antarctic Territory. GLOBAL DistRIBUTION: cosmopolitan.

(Øvstedal \& Lewis Smith 2001; Stenroos 1995).

Cladonia pycnoclada (Pers.) Nyl.

HABITAT ECOLOGY: on soil on peatlands and in rainforests, oceanic. ReCORDS IN Aisen: Jeinimeni, Tamango, Laguna San Rafael and Tortel. Distribution IN Chile: Juan Fernández Archipiélago, and from Curicó to Tierra del Fuego and Antarctic Territory. Global Distribution: the species is known in southern South America and Tristán de Cunha.

(Øvstedal \& Lewis Smith 2001; Stenroos 1995).

Cladonia pyxidata (L.) Hoffm.

Habitat eCOlOgY: on rocks and acidic soil in exposed habitats. ReCords in Aisen: Tamango, Tortel and Laguna San Rafael. Distribution in Chile: Cautín Province to Tierra del Fuego and Antarctic Territory. Global distribution: cosmopolitan.

(Øvstedal \& Lewis Smith 2001; Stenroos 1995).

Cladonia rangiferina (L.) F.H. Wigg.

HABITAT ECOlOGY: on soil in open habitats, in forest margins and steppe. ReCords in Aisen: Tamango and Tortel. Distribution in Chile: Temuco to Tierra del Fuego and Antarctic Territory. Global DistRiBution: bipolar. (Øvstedal \& Lewis Smith 2001; Stenroos 1995).

Cladonia robinsii A. Evans

HABitAT ECOLOGY: on bare soil on dry slopes and in Nothofagus forests. ReCords in Aisen: Carretera Austral between Cochrane and Villa O'Higgins. Distribution in Chile: Valparaíso, Aisen. Global distribution: North and South America.

(Stenroos 1995; UACH-UDEC 2007, 2008).

Cladonia sarmentosa (Hook. f. \& Taylor) C.W. Dodge HABITAT ECOLOGY: on soil and rotten wood in open habitats, rarely in Nothofagus forests. RECORDS IN Aisen: Puerto Aisen and Laguna San Rafael. Distribution in Chile: Valdivia to Magallanes and Antarctic Territory. Global distribution: austral.

(Øvstedal \& Lewis Smith 2001; Stenroos 1995).

Cladonia scabriuscula (Delise) Leight.

HABITAT ECOLOGY: on soil in open habitats and in Nothofagus forests. Records in Aisen: Coyhaique and Laguna San Rafael. Distribution in ChiLE: Juan Fernández Archipiélago, and from Limarí to Tierra del Fuego and Antarctic Territory. Global Distribution: cosmopolitan. 
(Øvstedal \& Lewis Smith 2001; Stenroos 1995).

Cladonia squamosa (Scop.) Hoffm.

HABITAT ECOLOGY: on soil and rotten wood in open and moist habitats, also in steppe, roadside scrub and open Nothofagus forests. ReCords in Aisen: Valle Exploradores and Laguna San Rafael. Distribution in Chile: Juan Fernández Archipiélago, and from Concepción to Tierra del Fuego and Antarctic Territory. Global Distribution: cosmopolitan. (Øvstedal \& Lewis Smith 2001; Stenroos 1995).

\section{Cladonia subchordalis A. Evans}

HaBitat ECOlOGY: on soil and stumps, in open rocky slopes, roadside and rainforests. ReCORDS IN AISEN: Coyhaique. Distribution in Chile: Juan Fernández Archipiélago, and from Nuble Province to Magallanes and Antarctic Territory. GLOBAL DisTRIBUTION: southern South America.

(Øvstedal \& Lewis Smith 2001; Stenroos 1995).

\section{Cladonia subsquamosa Kremp.}

HABITAT ECOlOGY: on soil and rotten wood in rainforests, forest margins and roadside scrub. RECORDS IN AISEN: Tamango and Laguna San Rafael. Distribution in Chile: Valdivia to Magallanes. GLOBAL DISTRIBUtion: pantropical. (Stenroos 1995).

\section{Cladonia subsubulata Nyl.}

Habitat ecology: on soil in open sites. Records in Aisen: Laguna San Rafael and on the road to Puerto Yungay. Distribution in Chile: Osorno to Tierra del Fuego and Antarctic Territory. Global Distribution: austral. (Øvstedal \& Lewis Smith 2001; Stenroos 1995).

Cladonia symphycarpia (Flörke) Fr.

HaBitat ECOlOGY: on peat, bogs, cushion heaths. ReCORDS IN Aisen: Coyhaique and Laguna San Rafael. Distribution IN Chile: Aisen to Magallanes. Global Distribution: austral. (Stenroos 1995).

Cladonia tessellata Ahti \& Kashiw.

HABitat ECOlogy: on sandy soil in open habitats. ReCords In Aisen: Coyhaique. Distribution in Chile: Juan Fernandez Archipelago, and from Valdivia to Magallanes. GlobaL Distribution: endemic to southern South America. (Stenroos 1995).

Cladonia ustulata (Hook f. \& Taylor) Leight.

Habitat ecology: on rotten wood, on mossy soil; most common in Nothofagus forests in open habitats. RECORDS IN Aisen: Coyhaique, Lago General Carrera and on the road to Puerto Yungay. Distribution in Chile: Cautín Province to Tierra del Fuego and Antarctic Territory. Global DISTRIBUTION: austral.

(Øvstedal \& Lewis Smith 2001; Stenroos 1995).
Coccocarpia dominguensis Vain.

Habitat ecology: on living leaves of trees and shrubs in rainforests. ReCORdS IN AISEN: Laguna San Rafael. Distribution in Chile: Valdivia to Magallanes. Global DISTRIBUTION: pantropical.

(Arvidsson 1983; Galloway 1992a; Lücking et al. 2003).

\section{Coccocarpia erythroxyli (Spreng.) Swinscow \& Krog} Habitat eCology: an epiphyte on trees and shrubs, also on living leaves and rocks. ReCORDS IN Aisen: Laguna San Rafael. Distribution in Chile: Valdivia to Aisen. Global DISTRIBUTION: pantropical.

(Lücking et al. 2003).

Coccocarpia palmicola (Spreng.) Arv. \& D.J. Galloway HABITAT ECOLOGY: on tree trunks, rarely on living leaves in rainforests. RECORDS IN AISEN: Valle Exploradores and Laguna San Rafael. Distribution in Chile: Valdivia to Magallanes. GlobAL DistRIBUTION: tropical-subtropical.

(Arvidsson 1992).

Coccotrema coccophorum (Mont.) I. Schmitt, Messuti \& Lumbsch

HABITAT ECOLOGY: an epiphyte of trees and shrubs in Valdivian rainforests, from sea level to $600 \mathrm{~m}$ altitude. Records IN Aisen: Queulat, Isla Magdalena, Tamango, Laguna San Rafael, Valle Exploradores, on the roadside to Puerto Yungay and Katalalixar. Distribution in Chile: Valdivia to Magallanes. Global Distribution: apparently endemic to southern South America.

(Galloway 1992a; Galloway \& Watson-Gandy 1992; Schmitt et al. 2001).

Coccotrema cucurbitula (Mont.) Müll. Arg.

HABITAT ECOLOGY: on trunks and twigs, rarely on rocks, in rainy zones. RECORDS IN AISEN: Queulat, Jeinimeni and Laguna San Rafael. Distribution in ChiLE: Malalcahuello to Isla Navarino and Antarctic Territory. GlobAL DISTRIBUTION: austral.

(Messuti 1996; Øvstedal \& Lewis Smith 2001; Redón \& Quilhot 1977).

Coccotrema porinopsis (Nyl.) Imsh. ex Yoshim.

HABITAT ECOlOGY: an epiphyte on trees and shrubs in Valdivian rainforest. RECORDS IN Aisen: Laguna San Rafael. Distribution in Chile: Llanquihue to Aisen. Global DISTRIBUTION: tropical.

(Messuti 1996).

Coelopogon epiphorellus Brusse \& Kärnefelt

HabitAT ECOLOGY: principally in Nothofagus forests, also on rocks; frequent in steppe and alpine areas. RECORDS IN AISEN: Queulat, Jeinimeni, Tamango and Tortel. DisTRIBUTION IN CHILE: La Campana National Park, Talca to Isla Navarino and Antarctic 
Territory. Global Distribution: South American-African. (Brusse \& Kärnefelt 1991; Øvstedal \& Lewis Smith 2001; Redón \& Quilhot 1977; Redón \& Walkowiak 1978).

\section{Coenogonium luteum (Dicks.) Kalb \& Lücking}

HABITAT ECOLOGY: on bark of tree trunks and on living leaves in humid and shaded sites. ReCORDS IN AISEN: Carretera Austral between Cochrane and Villa O'Higgins. Distribution in Chile: Federico Albert National Reserve, Malalcahuello to Aisen. GlobAl Distribution: the species is found worl-wide, foliicolous specimens have been reported from tropical regions.

(Lücking \& Kalb 2000; UACH-UDEC 2007, 2008).

\section{Collema glaucophthalmum $\mathrm{Nyl}$.}

HABITAT ECOLOGY: an epiphyte of trees and shrubs in very humid habitats. RECORDS IN Aisen: Queulat and Valle Exploradores. Distribution in Chile: Talca to Aisen. Global DISTRIBUTION: pantropical.

(Filson 1992).

Degelia duplomarginata (P. James \& Henssen) Arv. \& D.J. Galloway

HABITAT ECOLOGY: an epiphyte of trees and shrubs in humid forests. RECORDS IN Aisen: Queulat, Valle Exploradores, Laguna San Rafael and on the roadside to Puerto Yungay. Distribution in Chile: Enco (X Región) to Magallanes. GLOBAL DisTRIBUTION: known from southern South American, Tasmania, Australia, New Zealand and Hawaii.

(Arvidsson \& Galloway 1981).

Degelia flabellata P.M. Jørg. \& P. James

HABITAT ECOLOGY: an epiphyte of trees and shrubs, also on rocks in rainforests. RECORDS In Aisen: Laguna San Rafael. Distribution in Chile: the species in known only in Aisen. Global Distribution: known in the Southern Hemisphere, in Western Australia and Chile.

(Jørgensen \& Galloway 1992)

Degelia gayana (Mont.) Arv. \& D.J. Galloway

Habitat eCOlOgY: an epiphyte of trees and shrubs in rainforests moderately shaded. RECORDS IN AISEN: Queulat, Valle Exploradores, Laguna San Rafael and Tortel. Distribution in Chile: Enco (X Región) to Aisen. Global DISTRIBUTION: paleo-austral.

(Arvidsson \& Galloway 1981; Jørgensen \& Galloway 1992).

Degeliella versicolor (Müll. Arg.) P.M. Jørg. HABITAT ECOLOGY: an epiphyte of trees and shrubs in shaded forests. RECORDS In Aisen: Laguna San Rafael and Valle Exploradores. Distribution in Chile: Los Queñes (VII Región) to Tierra del Fuego. Global Distribution: austral. (Galloway \& James 1985; Jørgensen 2004).
Dictyonema glabratum (Spreng.) D. Hawksw.

HABITAT ECOLOGY: on mosses, soil, trees and shrubs in rainforests, also in steppe areas. RECORDS IN AISEN: Queulat, Vagabundo, Valle Exploradores, Laguna San Rafael, on the roadside to Puerto Yungay and Tortel. Distribution in Chile: Putre, Cerro Moreno (Antofagasta), Juan Fernández Archipiélago, and from Talca to Magallanes. GLobAL DISTRIBUTION: pantropical.

(Parmasto 1978).

Erioderma leylandii (Taylor) Müll. Arg.

HABITAT ECOLOGY: an epiphyte of shrubs, rarely on tree trunks, in rainforests. RECORDS IN AISEN: Queulat, Vagabundo, Valle Exploradores, Laguna San Rafael and on the roadside to Puerto Yungay. Distribution in Chile: Enco (X Región) to Magallanes. GlobAL Distribution: pantropical.

(Galloway 1992a; Jørgensen \& Galloway 1992).

Erioderma sorediatum D.J. Galloway \& P.M. Jørg. HABITAT ECOLOGY: an epiphyte of shrubs in very humid forests. Records in Aisen: Queulat, Laguna San Rafael, on the roadside to Puerto Yungay and Tortel. Distribution IN Chile: Enco (X Región) to Magallanes. Global Distribution: paleotropical.

(Jørgensen \& Galloway 1992).

Everniastrum sorocheilum (Vain.) Hale ex Sipman

Habitat ecology: an epiphyte of trees and shrubs in open sites. Records in Aisen: Queulat, Tamango and Laguna San Rafael. Distribution in Chile: Valparaíso to Curicó, Temuco to Magallanes. GLOBAL DistribUTION: austral-pantropical. (Adler \& Calvelo 2002; Sipman 1986).

\section{Fellhanera dominicana (Vain.) Vĕzda}

HABITAT ECOLOGY: on living leaves of shrubs in Valdivian rainforest. RECORDS INAISEN: Laguna San Rafael. DistribUTION IN Chile: Valdivia to Aisen. Global Distribution: mainly tropical America.

(Lücking 1992).

Flavoparmelia caperata (L.) Hale

HABITAT ECOlOGY: epiphyte on trees and shrubs in open sites. Records in Aisen: Valle Exploradores, and $10 \mathrm{~km} \mathrm{~S}$ of Tortel. Distribution in Chile: Zapahuira and Putre $(3350 \mathrm{~m}$ elevation) to Isla Navarino Global Distribution: North and South America, Europe, Asia, Africa.

(Galloway 1998; Nash III \& Elix 2002a; Redón \& Quilhot 1977).

Flavoparmelia gerlachei (Zahlbr.) Hale

Habitat ECOlOGY: an epiphyte in Nothofagus forests in steppe areas. Records in Aisen: Tamango. Distribution in Chile: Aisen to Magallanes and Antarctic Territory. Global DISTRIBUTION: southern South America and Antarctica. 
(Øvstedal \& Lewis Smith 2001).

Flavoparmelia soredians (Nyl.) Hale

HABItAT ECOlOGY: an epiphyte of forest trees, also on rocks from rainforests to arid habitats. RECORDS IN AISEN: on the roadside to Puerto Yungay. Distribution in Chile: Santiago, Concepción, Aisen and Magallanes. Global distribution: sub-cosmopolitan.

(Bjerke \& Elvebakk 1999).

Fuscopannaria minor (Darb.) P.M. Jørg.

Habitat ECOlogy: on bark trees. ReCORDS In Aisen: Carretera Austral between Cochrane and Villa O'Higgins. Global DISTRIBUTION: austral.

(Jørgensen 1999; UACH-UDEC 2007, 2008).

Fuscopannaria subimmixta (C. Knight) P.M. Jørg.

Habitat eCology: on the ground and on bark trees. Records IN Aisen: Carretera Austral between Cochrane to Villa O’Higgins. Global Distribution: austral.

(Jørgensen 1999; UACH-UDEC 2007, 2008).

Gowardia nigricans (Ach.) P. Halonen, L. Myllys, S. Velmala \& H. Hyvärinen

HABITAT ECOLOGY: an epiphyte of large trees, in habitats of high humidity; from sea level to $1100 \mathrm{~m}$ elevation. RECORDS in Aisen: Tamango and Tortel. Distribution in Chile: Valdivia to Isla Navarino. Global DISTRIBUtion: circumpolar.

(Brodo \& Hawksworth 1977; Halonen et al. 2009; Redón \& Quilhot 1977).

\section{Hypogymnia antarctica (Bitter) C.W. Dodge}

HaBitAT ECOlOGY: an epiphyte of Nothofagus pumilio. ReCORDS IN Aisen: Tamango (800-1000 m altitude). Distribution in Chile: Llanquihue to Isla Navarino and Antarctic Territory. Global DISTRIBUTION: cosmopolitan.

(Øvstedal \& Lewis Smith 2001; Redón 1985; Redón \& Quilhot 1977).

Hypogymnia bitteri (Lynge) Ahti

Habitat eCOlOgY: an epiphyte of Nothofagus in montane and subalpine forests. ReCORDS IN Aisen: Jeinimeni and Tamango. Distribution IN Chile: Llanquihue to Magallanes. Global Distribution: circumpolar, boreal, and montane. (McCune 2002; Redón 1974).

\section{Hypogymnia lugubris (Pers.) Krog}

HABITAT ECOLOGY: an epiphyte on tree trunks, on rock and soil in subalpine and alpine zones. RECORDS IN AISEN: Jeinimeni and Tamango (700-1100 m altitude). Distribution In Chile: Llanquihue to Isla Navarino and Antarctic Territory. GLOBAL DISTRIBUTION: bipolar.

(Øvstedal \& Lewis Smith 2001; Redón 1974; Redón \& Quilhot 1977).
Hypogymnia mundata (Nyl.) Rassad.

Habitat ecology: an epiphyte on tree trunks in shady sites. ReCords in Aisen: Jeinimeni and Tamango. Distribution IN Chile: Malleco Province to Magallanes. Global DISTRIBUTION: austral.

(Elix 1992).

Hypogymnia pulchrilobata (Bitter) Elix

HABITAT ECOLOGY: an epiphyte on tree trunks in shady sites. Records in Aisen: Tamango. Distribution in Chile: Valdivia to Magallanes. Global DistRiBution: austral.

(Elix 1992).

Hypogymnia subphysodes (Kremp.) Filson var. subphysodes (Kremp.) Filson

HABITAT ECOLOGY: on dead wood, bark, twigs and rocks in humid and temperate rainforests. RECORDS IN AIsEn: Queulat, Coyhaique Alto, Jeinimeni, Tamango, Valle Exploradores, Laguna San Rafael, Vagabundo, on the roadside to Puerto Yungay and Katalalixar. Distribution IN Chile: Fray Jorge National Park, Talca to Magallanes. GlobAl Distribution: austral.

(Elix 1992).

Hypogymnia turgidula (Bitter) Elix

HABITAT ECOLOGY: an epiphyte of trunks and twigs in Nothofagus forests. ReCords in Aisen: Tamango and on the roadside to Puerto Yungay. Distribution in Chile: Malleco Province to Magallanes. Global DISTRIBUTION: austral.

(Elix 1992).

Hypotrachyna brevirhiza (Kurok.) Hale

HABITAT ECOLOGY: an epiphyte of trees and shrubs in humid forests, occasionally on rocks in montane to subalpine forests. ReCords IN Aisen: Jeinimeni, Tamango, Vagabundo and Laguna San Rafael. Distribution in ChiLE: Isla Mocha to Magallanes. Global Distribution: pantropical and extending to temperate areas of Argentina and Chile.

(Nash III et al. 2002; Quilhot et al. 2010).

Hypotrachyna flavovirens (Kurok.) Hale

Habitat ecology: an epiphyte on trunks of Nothofagus pumilio and other forestry species in humid forests. RECORDS in Aisen: Tamango. Distribution in Chile: Valdivia to Isla Navarino. Global Distribution: endemic to southern South America.

(Hale 1975; Redón \& Quilhot 1977).

Hypotrachyna laevigata ( $\mathrm{Sm}$.) Hale

HABITAT ECOLOGY: an epiphyte of trees and shrubs in open sites. ReCords in Aisen: Tamango, Vagabundo and Laguna San Rafael. Distribution in Chile: Talca to Magallanes. Global Distribution: cosmopolitan.

(Hale 1974, Nash III et al. 2002). 
Hypotrachyna livida (Taylor) Hale

HABitat ecology: an epiphyte of trees in humid forests; rarely on acidic rocks. ReCORDS IN Aisen: Laguna San Rafael. Distribution in Chile: Valdivia to Magallanes. Global DISTRIBUTION: neotropical.

(Hale 1974; Nash III et al. 2002).

\section{Hypotrachyna oostingii (Dey) Hale}

HABitat ECOlOGY: an epiphyte of trees and shrubs in open sites. Records in Aisen: Laguna San Rafael. Distribution in Chile: Valdivia to Magallanes. Global Distribution: bipolar.

(Hale 1974, 1975).

\section{Hypotrachyna physcioides (Nyl.) Hale}

HABITAT ECOLOGY: on rocks, soil and bark in rainforests in open sites. Records in Aisen: Laguna San Rafael. Distribution in Chile: Valdivia to Magallanes. Global Distribution: through-out the neotropics, including the Caribbean, also in the SE of Asia.

(Hale 1975; Nash III et al. 2002).

\section{Hypotrachyna rachista (Hale) Hale}

HABITAT ECOLOGY: an epiphyte on trees and shrubs. RECORDS in Aisen: Laguna San Rafael. Distribution in Chile: Valdivia to Magallanes. Global DISTRIBUtion: neotropical.

(Hale 1974, 1975).

\section{Hypotrachyna rockii (Zahlbr.) Hale}

HABITAT ECOLOGY: usually on bark in montane forests. Records in Aisen: Laguna San Rafael. Distribution in Chile: Valdivia to Magallanes. Global Distribution: neotropics and East Africa

(Hale 1974; Nash III et al. 2002).

\section{Hypotrachyna sinuosa (Sm.) Hale}

HABitat eCOlOGY: an epiphyte of trees and shrubs in open sites. Records in Aisen: Tamango, Jeinimeni, Valle Exploradores, Laguna San Rafael and Tortel. Distribution in Chile: Rancagua to Magallanes. Global distribution: cosmopolitan.

(Elix 1994; Hale 1974).

Jackelixia ligulata (Körb.) S.Y. Kondr., Fedorenko, S. Stenroos, Kärnefelt \& Thell

Habitat ecology: on rocks in open sites. Records in Aisen: Laguna San Rafael. Distribution in Chile: Valdivia to Magallanes. Global Distribution: australasian.

(Fedorenko et al. 2009; Galloway 1985, 1992a).

Lecanora argentata (Ach.) Degel.

Habitat ECOlOgy: a corticolous species of exposed habitats. ReCords In Aisen: Carretera Austral from Cochrane to Villa O'Higgins. Distribution in Chile: Valdivia to Magallanes.
GLOBAL DISTRIBUTION: cosmopolitan.

(Lumbsh \& Elix 2004; UACH-UDEC 2007, 2008).

Lecanora dispersa (Pers.) Sommerf.

Habitat ecology: on rocks and mosses. Records in Aisen: Tamango. Distribution in Chile: Valparaíso, Santiago, Talca, and from Valdivia to Magallanes. Global Distribution: cosmopolitan.

(Galloway 1985).

Lecanora epibryon (Ach.) Ach. ssp. broccha (Nyl.) Lumbsch

HABitat ECOlOgY: on soil, mosses and rocks in open sites. Records in Aisen: Tamango. Distribution in Chile: TrapaTrapa (Alto Bio-Bio, VIII Región) to Aisen and Antarctic Territory. GLOBAL DISTRIBUTION: bipolar.

(Lumbsch \& Elix 2004; Øvstedal \& Lewis Smith 2001).

Lecidea atrobrunnea (Lam. \& D.C.) Schaer.

HaBitAT ECOlOgY: on rocks and amongst mosses in steppe areas. Records in Aisen: Tamango. Distribution in Chile: Santiago to Colchagua Province, Aisen to Magallanes and Antarctic Territory. GLOBAL DISTRIBUTION: bipolar.

(Hertel 2007; Øvstedal \& Lewis Smith 2001; Rambold 1989).

\section{Lecidea fuscoatrula $\mathrm{Nyl}$.}

Habitat ecology: on rocks in open sites. Records in Aisen: Tamango. Distribution in Chile: Valparaíso to Magallanes. Global distribution: the species is known in South Africa and Australasia.

(Hertel 1997, 2001).

Leifidium tenerum (Laurer) Wedin

Habitat ECOlOgy: an epiphyte of trees, also on rocks in humid forests from sea level to $600 \mathrm{~m}$ altitude. RECORDS IN Aisen: Queulat, Isla Magdalena, Puerto Aisen, Lago Riesco, Valle Exploradores, Laguna San Rafael, Vagabundo, on the road to Puerto Yungay, Tortel and Katalalixar. Distribution in Chile: Valdivia to Magallanes. Global distribution: austral.

(Wedin 1995).

Leioderma pycnophorum Nyl.

Habitat eCOlogy: an epiphyte of shrubs and trees in rainforests. Records IN Aisen: Queulat, Isla Magdalena, Valle Exploradores, Laguna San Rafael, Puerto Yungay and Katalalixar. Distribution in Chile: Valdivia to Magallanes. GLOBAL DistRibution: austral.

(Galloway \& Jørgensen 1987).

Lepraria neglecta (Nyl.) Erichsen

Habitat eCOlogy: on rocks and amongst mosses. Records in Aisen: Tamango. Distribution in Chile: Juan Fernández 
Archipiélago, and from Aisen to Magallanes and Antarctic Territory. GlOBAL DISTRIBUTION: bipolar. (Kümmerling et al. 1993; Øvstedal \& Lewis Smith 2001).

Leptogium australe (Hook. f. \& Taylor) Müll. Arg. HABitat ECOlOgy: among mosses at sea level and above tree line, also on sand, rarely on coastal shrubs. RECORDS In Aisen: Queulat and Laguna San Rafael. Distribution in Chile: Isla Mocha to Magallanes. Global distribution: apparently endemic to southern South America.

(Galloway \& Jørgensen 1995; Quilhot et al. 2010).

Leptogium azureum (Sw. ex Ach.) Mont.

HABitat eCOlOgy: an epiphyte of trees and shrubs, also on rocks in shaded, humid situations in rainforests. RECORDS IN Aisen: Queulat, Valle Exploradores and Laguna San Rafael. Distribution in Chile: Cerro Moreno (Antofagasta); Fray Jorge National Park, Juan Fernández Archipiélago, La Campana National Park, and from Isla Mocha to Aisen. Global Distribution: cosmopolitan.

(Galloway \& Jørgensen 1995; Quilhot et al. 2010; Redón \& Walkowiak 1978).

\section{Leptogium brebissonii Mont.}

HABITAT ECOLOGY: among mosses, short grass and low vegetation in deep shade. ReCords In Aisen: Laguna San Rafael. Distribution in Chile: Isla Mocha to Aisen. Global DISTRIBUTION: bipolar.

(Galloway \& Jørgensen 1995; Quilhot et al. 2010).

Leptogium britannicum P.M. Jørg. \& P. James

HABITAT ECOLOGY: amongst short grass and low vegetation, on soil, between exposed coastal rocks. ReCords in Aisen: Valle Exploradores and Laguna San Rafael. Distribution IN Chile: Isla Mocha and Aisen. Global distribution: bipolar. (Galloway \& Jørgensen 1995; Quilhot et al. 2010).

Leptogium cochleatum (Dicks.) P.M. Jørg. \& P. James Habitat eCOlogy: on soil, among mosses in shaded, humid situations. ReCords in Aisen: Laguna San Rafael. Distribution in Chile: Isla Mocha to Aisen. Global DISTRIBUTION: widespread in the tropics and warm temperate regions.

(Galloway \& Jørgensen 1995; Quilhot et al. 2010).

Leptogium coralloideum (Meyen \& Flot.) Vain.

Habitat ecology: an epiphyte both in open forests and especially on riverine trees and shrubs. RECORDS IN AISEN: Carretera Austral $10 \mathrm{~km} \mathrm{~N}$ of Murta, Valle Exploradores and Laguna San Rafael. Distribution in Chile: Isla Mocha to Aisen. Global Distribution: tropical to warm-temperate distribution.

(Galloway \& Jørgensen 1995; Quilhot et al. 2010).
Leptogium cyanescens (Rabenh.) Körber

HABITAT ECOlOGY: in humid, deeply shaded habitats in Nothofagus forests, also among mosses. Records in Aisen: Queulat, Tamango and Laguna San Rafael. Distribution in Chile: Valdivia to Aisen. Global distribution: rather cosmopolitan in temperate and subtropical regions.

(Galloway \& Jørgensen 1995).

\section{Leptogium decipiens P.M. Jørg.}

Habitat ECOlogy: an epiphyte of trees in humid rainforests, on roadside trees and shrubs in shade, also on rocks. RECORDS in Aisen: Queulat and Laguna San Rafael. Distribution IN CHiLE: Isla Mocha, and from Puyehue to Magallanes. Global Distribution: endemic to southern South America. (Galloway \& Jørgensen 1995; Quilhot et al. 2010).

Leptogium juressianum $\mathrm{C}$. Tav.

HaBitat ECOlOgY: an epiphyte of twigs and shrubs both in shaded, humid rainforests. ReCords in Aisen: Queulat, Río Pangal, Puerto Aisen, Valle Exploradores and Laguna San Rafael. Distribution in Chile: Puyehue to Aisen. Global DISTRIBUTION: the species is known from Occidental Europe, East Africa and northern Andes.

(Galloway \& Jørgensen 1995).

Leptogium laceroides de Lesd.

HaBitat ECOlOgY: an epiphyte of shrubs and trees both in shaded, humid rainforests. Records IN Aisen: Tamango and Laguna San Rafael. Distribution in Chile: Conguillio National Park to Aisen. Global distribution: the species is known from Mexico, Tristán de Cunha, East Africa and New Zealand.

(Galloway \& Jørgensen 1995).

Leptogium menziesii (Ach.) Mont.

HaBitAT ECOlOgY: amongst mosses on trees and shrubs in rather open situations. RECORDS IN AISEN: Valle Exploradores and Laguna San Rafael. Distribution in Chile: La Campana National Park, and from Isla Mocha to Isla Navarino. Global Distribution: austral.

(Galloway 1992a; Galloway \& Jørgensen 1995; Quilhot et al. 2010; Redón \& Quilhot 1977; Redón \& Walkowiak 1978).

Leptogium malmei P.M. Jørg.

HABITAT ECOLOGY: an epiphyte of trees and shrubs in densely shaded, humid rainforests. RECORDS IN AIsen: Queulat, Río Aisén and Valle Exploradores. Distribution IN ChiLE: known only in Aisen. Global distribution: austral.

(Galloway \& Jørgensen 1995).

Leptogium phyllocarpum (Pers.) Mont.

HABitAT ECOlOGY: an epiphyte of trees and shrubs. RECORDS IN Aisen: Rio Pangal (10 m NE of Puerto Aisen). Distribution 
in Chile: Puerto Montt to Aisen. Global distribution: a widespread tropical-subtropical species.

(Galloway \& Jørgensen 1995).

Leptogium valdivianum $\mathrm{M}$. Lindstr.

HABitaT ECOlOGY: on trees and shrubs in humid rainforests or closed to forests margins. RECORDS IN AISEN: Laguna San Rafael. Distribution in Chile: Valdivia to Magallanes. Global Distribution: probably endemic to southern South America.

(Galloway \& Jørgensen 1995).

Mastodia tesellata (Hoof. f. \& Harv.) Hoof. f. \& Harv. HABitat ECOlogy: on coastal rocks. ReCORds in Aisen: Laguna San Rafael. Distribution in Chile: Aisen to Magallanes and Antarctic Territory. Global Distribution: circum-pacific. (Galloway 1992a, 2007; Øvstedal \& Lewis Smith 2001).

Mazosia phyllosema (Nyl.) Zahlbr.

HABITAT ECOLOGY: on living leaves in humid forests. RECORDS in Aisen: Laguna San Rafael. Distribution in Chile: Valdivia to Aisen.Global Distribution: pantropical.

(Galloway 2007; Lücking 1992).

Melanelia subglabra (Räsänen) Essl.

HABITAT ECOLOGY: and epiphyte of trees, particularly in Nothofagus forests. ReCORDS IN Aisen: Jeinimeni, Tamango and Laguna San Rafael. Distribution In Chile: Antuco (VIII Región) to Aisen. GlobAl Distribution: a southamerican and australasian species.

(Adler \& Calvelo 2002; Galloway 2007).

Melanohalea ushuaiensis (Zahlbr.) Essl.

Habitat ECOlogy: an epiphyte in Nothofagus forests in steparic and alpine areas. RECORDS IN AISEN: Jeinimeni and Tamango. Distribution in Chile: Termas de Chillán (VIII Región) to Isla Navarino and Antarctic Territory. GlobAL DISTRIBUTION: southern South America and Antarctica.

(Blanco et al. 2004; Øvstedal \& Lewis Smith 2001; Redón \& Quilhot 1977).

Menegazzia chrysogaster Bjerke \& Elvebakk

HABITAT ECOlOGY: an epiphyte of trees and shrubs in low to medium light situations in Nothofagus forests, about 150 $\mathrm{m}$ to $1400 \mathrm{~m}$ altitude. It is the only species of the genus in South America having a yellow medulla. RECORDS IN AISEN: Jeinimeni, Tamango and Laguna San Rafael. Distribution IN ChILE: Termas de Chillan (VIII Región) to Magallanes. Global Distribution: endemic to southern South America. (Bjerke \& Elvebakk 2001; Bjerke et al. 2003a).

Menegazzia cincinnata (Ach.) Bitter

Habitat ECOlogy: an epiphyte of trees in open sites. ReCORDS In Aisen: Queulat, Jeinimeni, Tamango, Valle Exploradores,
Laguna San Rafael, on the roadside to Puerto Yungay and Tortel. Distribution in Chile: Termas de Chillán (VIII Región) to Isla Navarino. Global Distribution: endemic to southern South America.

(Bjerke 2005, Redón \& Quilhot 1977).

Menegazzia dispora (Nyl. ex Cromb.) R. Sant.

Habitat ecology: an epiphyte of trees and shrubs. It is the most common species of Menegazzia in Valdivian and North Patagonian rainforests. RECORDS IN Aisen: Queulat and Laguna San Rafael. Distribution in Chile: Cautín Province to Tierra del Fuego. Global Distribution: austral.

(Bjerke 2005).

Menegazzia fumarprotocetrarica Calvelo \& Adler

HABitat ECOLOGY: an epiphyte of trees and shrubs in fairly open forests. RECORDS IN Aisen: Queulat, Jeinimeni, Tamango, Valle Exploradores and Laguna San Rafael. Distribution in Chile: Isla Mocha to Magallanes. Global DISTRIBUTION: endemic to southern South America.

(Adler \& Calvelo 1996b; Bjerke et al. 2003a; Quilhot et al. 2010).

Menegazzia globulifera $\mathrm{R}$. Sant.

HABITAT ECOLOGY: An epiphyte of trees and shrubs in light exposed relatively dry vegetation; it is also saxicolous, with altitudinal range from ca. 500 to $1800 \mathrm{~m}$.

Records in Aisen: Queulat, Jeinimeni, Tamango, Valle Exploradores, Laguna San Rafael, on the roadside to Puerto Yungay and Tortel. Distribution in Chile: Termas de Chillán (VIII Región) to Isla Navarino. Global Distribution: austral.

(Bjerke et al. 2003a; Quilhot et al. 2010; Redón \& Quilhot 1977).

Menegazzia hollermayeri (Räsänen) R. Sant.

HABITAT ECOLOGY: an epiphyte of trees and shrubs in open sites. RECORDS IN AISEN: Queulat, Jeinimeni, Tamango, Katalalixar, Vagabundo, Valle Exploradores, Laguna San Rafael, on the roadside to Puerto Yungay and Tortel. Distribution in Chile: Malalcahuello to Aisen. Global DISTRIBUTION: endemic to southern South America.

(Bjerke 2005).

Menegazzia kawesqarica Bjerke \& Elvebakk

HABITAT ECOLOGY: an epiphyte of large trees in forests from 800 to $1400 \mathrm{~m}$ altitude, rarely at sea level, with fairly high direct solar radiation; it is also common on shaded rock outcrops. Records in Aisen: Jeinimeni, Tamango and Laguna San Rafael. Distribution in Chile: Nahuelbuta National Park to Magallanes. GlobAl DISTRIBUTION: endemic to southern South America.

(Bjerke \& Elvebakk 2001; Bjerke et al. 2003a). 
Menegazzia megalospora (Räsänen) R. Sant.

HABitat ecology: an epiphyte of trees in humid forests. Records in Aisen: Laguna San Rafael. Distribution in Chile: Valdivia to Magallanes. Global distribution: endemic to southernmost South America. (Bjerke 2005).

\section{Menegazzia neozelandica (Zahlbr.) P. James}

HABITAT ECOlOgY: an epiphyte of trees and shrubs, also on mosses in Valdivian rainforests. RECORDS IN AISEN: Villa Ortega-Puyuhuapi, Lago Riesco, Laguna San Rafael, Vagabundo, and on the roadside to Puerto Yungay. Distribution in Chile: Fray Jorge National Park, Juan Fernández Archipiélago, and from Nahuelbuta National Park to Magallanes. Global Distribution: austral.

(Bjerke et al. 2003a).

\section{Menegazzia norsorediata Adler \& Calvelo}

HABITAT ECOLOGY: an epiphyte of trees and shrubs in both Valdivian rainforest and high altitude mixed deciduousconiferous forest, in microhabitats with variable light conditions. Records in Aisen: Queulat and Laguna San Rafael. Distribution in Chile: Nahuelbuta National Park to Magallanes. GLOBAL DISTRIBUTION: austral.

(Adler \& Calvelo 1996b; Bjerke et al. 2003a).

Menegazzia opuntioides (Müll. Arg.) R. Sant.

HaBitAT ECOlOGY: an epiphyte of trees and shrubs in Valdivian and Patagonian rainforests from sea level to $1400 \mathrm{~m}$ altitude. Records in Aisen: Río Cisnes, Lago Riesco, Vagabundo, Valle Exploradores and Laguna San Rafael. Distribution in Chile: Choshuenco (X Región) to Magallanes. Global Distribution: endemic to southernmost South America. (Bjerke et al. 2003a).

Menegazzia sanguinascens (Räsänen) R. Sant. HABITAT ECOLOGY: an epiphyte of trees in moderately to high humidity, with an altitudinal range from $100 \mathrm{~m}$ to $1400 \mathrm{~m}$. ReCords in Aisen: Queulat, Jeinimeni, Tamango, Laguna San Rafael, Katalalixar, on the roadside to Puerto Yungay and Valle Exploradores. Distribution In Chile: Nahuelbuta National Park to Isla Navarino. Global Distribution: austral.

(Bjerke et al. 2003a; Redón \& Quilhot 1977).

\section{Menegazzia subpertusa P. James \& D.J. Galloway}

HABITAT ECOLOGY: an epiphyte of trees and shrubs in rather sunny and dry microhabitats surrounded by well developed forests. RECORDS IN AISEN: on the road Villa Ortega-Puyuhuapi, Lago Riesco and Laguna San Rafael. Distribution in Chile: Termas de Chillán (VIII Región) to Magallanes. Global Distribution: austral.

(Bjerke et al. 2003a; Galloway 1983).
Menegazzia tenuis R. Sant.

Habitat ecology: in deep shaded habitats of high humidity, among mosses and tree bark. ReCORDS IN AISEN: Laguna San Rafael and on the roadside to Puerto Yungay. Distribution IN CHILE: Melipeuco and Icalma (IX Región) to Magallanes. Global Distribution: endemic to southern South America. (Bjerke et al. 2003a).

Menegazzia valdiviensis (Räsänen) $R$. Sant. HaBitat ECOlogy: an epiphyte on trees and shrubs, often in understory vegetation, avoiding the most low-light habitats. ReCordS In Aisen: Queulat, Valle Exploradores, Laguna San Rafael and on the roadside to Puerto Yungay. Distribution IN Chile: Nahuebuta National Park to Magallanes. Global DistRibution: endemic to southern South America.

(Bjerke et al. 2003a).

Menegazzia violascens (Räsänen) Bjerke

HABitat eCOlOgy: an epiphyte on trees and shrubs in Valdivian rainforest. RECORDS IN Aisen: Queulat, Valle Exploradores, and Laguna San Rafael. Distribution IN Chile: Nahuelbuta National Park to Isla Navarino. Global DISTRIBUTION: endemic to southern South America.

(Bjerke 2005).

\section{Menegazzia wandae Bjerke}

HABitat ECOlOgy: an epiphyte in Valdivian rainforests in moderate to dense shade. Distribution in Aisen: Rio Cisnes, Lago Riesco and Laguna San Rafael. Distribution in Chile: Isla Mocha to Aisen. Global Distribution: endemic to southern South America.

(Bjerke 2001; Bjerke et al. 2003a; Quilhot et al. 2010).

\section{Menegazzia wilsonii (Vain. ex Räsänen) Bjerke}

HABITAT ECOLOGY: an epiphyte of trees and shrubs, on mosses in shady and more light-open rainforests. RECORDS IN AISEN: Queulat, Lago Riesco, Carretera Austral $5 \mathrm{~km} \mathrm{~S}$ of Murta, Vagabundo, Valle Exploradores, Laguna San Rafael, on the roadside to Puerto Yungay and Tortel: Distribution IN Chile: Termas de Chillán (VIII Región) to Tierra del Fuego. Global Distribution: endemic to southern South America. (Bjerke 2005).

Metus efflorescens D.J. Galloway \& P. James Habitat ecology: on living and dead trees, also on rocks in open sites. ReCords IN AIsen: Laguna San Rafael. Distribution in Chile: from Conguillio National Park to Magallanes. Global Distribution: endemic to southern South America.

(Galloway 1992a; Galloway \& James 1987; Messuti et al. 2007).

Metus pileatus (Mont.) D.J. Galloway \& P. James

HABITAT ECOLOGY: on bark or decorticated wood, usually over 
mosses and hepatics in moist, shaded sites with moderate to high rainfall. Records in Aisen: Puerto Aisen. Distribution IN CHILE: from Conguillio National Park to Magallanes. Global Distribution: endemic to southern South America. (Galloway \& James 1987; Stenroos 1995).

\section{Nephroma analogicum $\mathrm{Nyl}$.}

HABITAT ECOLOGY: an epiphyte of trees and shrubs in moist sites and in high-light situations. RECORDS IN AISEN: Península de Taitao. Distribution In Chile: Juan Fernández Archipiélago, and from Conguillio National Park to Tierra del Fuego. Global Distribution: endemic to southern South America.

(White \& James 1988).

\section{Nephroma antarcticum (Jaq.) Nyl. var. antarcticum}

Habitat eCOlogy: an epiphyte of trees and shrubs, also on rocks in a wide range of light situations. RECORDS IN AISEN: Queulat, Isla Magdalena, Jeinimeni, Tamango, Vagabundo, Valle Exploradores, Laguna San Rafael, Tortel, Katalalixar. Distribution in Chile: Fray Jorge National Park, Juan Fernández Archipiélago, and from Talca to Isla Navarino. GlobAl Distribution: endemic to southern South America. (Galloway 1992a; Redón \& Quilhot 1977; White \& James 1988).

Nephroma antarcticum var. lobuligerum Müll. Arg. HABITAT ECOLOGY: an epiphyte of trees and shrubs in humid forests in a wide range of light situation. RECORDS in Aisen: Cochrane. Distribution in Chile: Juan Fernández Archipiélago, from Malleco Province to Magallanes. GlobAL DISTRIBUTION: endemic to southern South America.

(White \& James 1988).

Nephroma australe A. Rich.

HABITAT ECOLOGY: an epiphyte of trees and shrubs, rarely saxicolous, amongst mosses. ReCORds in Aisen: Puerto Aisen and Vagabundo. Distribution in Chile: Juan Fernández Archipiélago, and from Llanquihue to Magallanes. GlobAL DISTRIBUTION: austral.

(White \& James 1988).

Nephroma cellulosum (Ach.) Ach.

HaBitat ECOlOGY: an epiphyte of trees and shrubs in humid sites. Records in Aisen: Queulat, Jeinimeni, Tamango, Valle Exploradores, Laguna San Rafael, Tortel and Katalalixar. Distribution in Chile: Juan Fernández Archipiélago, and from Concepción to Isla Navarino. GlobAl Distribution: austral.

(Galloway 1992a; White \& James 1988).

Nephroma cellulosum var. isidioferum J. Murray

HABITAT ECOlOGY: an epiphyte of trees and shrubs in humid and shady sites. RECORDS IN Aisen: Queulat and Laguna
San Rafael. Distribution in Chile: Malalcahuello to Aisen. GlobAl Distribution: austral.

(White \& James 1988).

Nephroma chubutense I.M. Lamb

Habitat ecology: an epiphyte on trees, also on fallen trunks restricted to very humid habitats. RECORDS IN Aisen: Tamango. Distribution in Chile: from Conguillio National Park to Aisen. Global Distribution: endemic to southern South America.

(White \& James 1988).

Nephroma kuehnemannii I.M. Lamb

HABITAT ECOLOGY: an epiphyte on trees and shrubs confined to the Valdivian and Patagonian rainforests. RECORDS IN Aisen: Vagabundo. Distribution in Chile: from Conguillio National Park to Aisen. Global Distribution: endemic to southern South America.

(White \& James 1988).

\section{Nephroma microphyllum Henssen}

Habitat eCology: an epiphyte of trees and shrubs in open, humid and shady sites. Records in Aisen: Queulat, Puerto Aisen and Vagabundo. Distribution in Chile: Temuco to Aisen. Global Distribution: endemic to southern South America.

(White \& James 1988).

Nephroma parile (Ach.) Ach.

Habitat ecology: An epiphyte of tree trunks in Nothofagus forests. RECORDS IN AISEN: Jeinimeni and Tamango. Distribution in Chile: Conguillio National Park to Aisen. Global Distribution: cosmopolitan.

(James \& White 1987; White \& James 1988).

Nephroma plumbeum (Mont.) Mont. var. plumbeum HABitat ECOLOGY: an epiphyte on trees and shrubs in Valdivian raiforest. Records in Aisen: Puerto Aisen and Laguna San Rafael. Distribution in Chile: Juan Fernandez Archipelago, La Campana National Park, from Enco (X Región) to Aisen. Global Distribution: austral.

(White \& James 1988).

Nephroma plumbeum (Mont.) Mont. var. isidiatum (J. Murray) F.J. White \& P. James

HABITAT ECOLOGY: an epiphyte on trees and shrubs in Valdivian rainforest. Records in Aisen: Puerto Aisen. Distribution in Chile: Chiloé to Aisen. Global Distribution: austral.

(White \& James 1988).

Neproma pseudoparile (Räsänen) Zahlbr.

HABITAT ECOLOGY: an epiphyte on trees and shrubs often in open forests, also close to rivers and streams in rather arid zones. Records in Aisen: Coyhaique Bajo, Baquedano, Río 
Simpson, Tamango. Distribution in Chile: Juan Fernández Archipiélago, from Los Vilos to Valparaíso, and from Nuble to Magallanes. GlobAL DisTribution: endemic to southern South America.

(White \& James 1988).

Nephroma skottsbergii F.J. White \& P. James

HABITAT ECOLOGY: an epiphyte of trees and shrubs in humid habitats. Records in Aisen: Queulat and Laguna San Rafael. Distribution in Chile: Conguillio National Park to Aisen. Global Distribution: endemic to southern South America.

(White \& James 1988).

Normandina pulchella (Borrer) Nyl.

HABITAT ECOLOGY: on bark of trees and shrubs, also on living leaves in high humidity and shade situations. RECORDS In Aisen: Valle Exploradores and Laguna San Rafael. Distribution in Chile: Juan Fernández Archipiélago, and from Isla Mocha to Magallanes. Global Distribution: cosmpolitan.

(Galloway 1985; Quilhot et al. 2010).

Ochrolechia pallescens (L.) A. Massal.

HABITAT ECOLOGY: an epiphyte on tree trunks in open sites. Records in Aisen: Jeinimeni and Tamango. Distribution in Chile: Talca to Isla Navarino. Global Distribution: cosmopolitan.

(Galloway 1985; Redón \& Quilhot 1977).

Pannaria calophylla (Müll. Arg.) Passo \& Calvelo HaBitat ECOlOGY: an epiphyte of trees and shrubs, also on leaves in habitats with high humidity. RECORDS IN Aisen: Queulat and Laguna San Rafael. Distribution in Chile: from Valdivia to Aisen. Global Distribution: austral. (Galloway 1992a; Passo \& Calvelo 2006).

Pannaria conoplea (Ach.) Bory

HABITAT ECOLOGY: on the bark of tree trunks, also on mosses in open sites. ReCords In Aisen: Puerto Aisen, Jeinimeni and Tamango. Distribution in Chile: Antuco to Aisen. Global DISTRIBUTION: pantemperate.

(Galloway et al. 2006).

Pannaria farinosa Elvebakk \& J. Fritt Rasm.

HABITAT ECOlOGY: an epiphyte of trees and shrubs, also on mosses and rocks, in both humid areas along the coast and in the easternmost deciduous Nothofagus forests. RECORDS IN Aisen: Queulat, Valle, Exploradores and Laguna San Rafael. Distribution in Chile: Juan Fernández Archipiélago, Fray Jorge National Park, and from Talca to Isla Navarino. GLOBAL Distribution: panaustral.

(Elvebakk et al. 2007).

Pannaria hispidula (Nyl.) Hue

Habitat ecology: on trunks in Nothofagus forests in sites with high humidity.

Records In Aisen: Laguna San Rafael and Katalalixar. Distribution in Chile: Valdivia to Isla Navarino. Global DISTRIBUTION: cosmopolitan.

(Jørgensen 2006; Passo et al. 2008).

Pannaria implexa (Stirt.) Passo, Calvelo \& S. Stenroos Habitat eCOlogy: an epiphyte of trees and shrubs, rocks, soil, amongst mosses in sites with high humidity. RECORDS in Aisen: Laguna San Rafael. Distribution in Chile: Juan Fernández Archipiélago, and from Villarrica to Magallanes. Global Distribution: austral.

(Passo et al. 2008).

Pannaria isabellina (Vain.) Elvebakk \& Bjerke

Habitat ecology: on light-exposed twigs in forest margins, also on basal trunks. Records in Aisen: Río Aisen, Puerto Aisen and Valle Exploradores. Distribution in Chile: Isla Mocha, and from Riñihue (X Región) to Magallanes. Global Distribution: endemic to southern South America. (Elvebakk \& Bjerke 2005; Quilhot et al. 2010).

Pannaria microphyllizans (Nyl.) P.M. Jørg.

HABITAT ECOLOGY: an epiphyte of trees, also on rotten wood in habitats with high humidity. RECORDS IN Aisen: Queulat and Laguna San Rafael. Distribution in Chile: Huerquehue National Park to Aisen. Global Distribution: australasian. (Galloway 1992a; Passo et al. 2008).

Pannaria pallida (Nyl.) Hue

Habitat ecology: an epiphyte of trees and shrubs in moderate light situations. RECords IN Aisen: Queulat, Laguna San Rafael and Carretera Austral $55 \mathrm{~km} \mathrm{~S}$ of Cochrane. Distribution in Chile: Talca to Isla Navarino. GlobAl Distribution: austral.

(Jørgensen 2006).

Pannaria sphinctrina (Mont.) Tuck.

Habitat eCOlOGy: an epiphyte on trees and shrubs, also on mosses, in habitats with high humidity. RECORDS IN Aisen: Queulat, Puerto Aisen, Valle Exploradores and Laguna San Rafael. Distribution in Chile: Juan Fernández Archipiélago, and from Valdivia to Tierra del Fuego. Global Distribution: cosmopolitan.

(Elvebakk 2007; Galloway 1992a).

\section{Pannaria tavaresii P.M. Jørg.}

Habitat ecology: an epiphyte on trees, also on mosses and rocks in open sites. RECORDS IN AISEN: Jeinimeni (1100 m altitude). Distribution in Chile: from Laguna de la Laja National Park to Aisen. Global Distribution: the species has a warm temperate, subtropical distribution.

(Galloway et al. 2006). 
Pannoparmelia angustata (Pers.) Zahlbr.

HABitat ECOlOgy: an epiphyte on trees and shrubs in open sites, from sea level to $1000 \mathrm{~m}$ altitude. Records in Aisen: Queulat, Tamango, Valle Exploradores, Laguna San Rafael and on the roadside to Puerto Yungay. Distribution in Chile: Bio-Bio Province to Magallanes. Global distribution: australasian.

(Galloway 1985, 1992a).

Parasiphula complanata (Hook. f. \& Taylor) Kantvilas \& Grube

Habitat ecology: on tree bark, also on soil in rainforests. Records in Aisen: Katalalixar. Distribution in Chile: Valdivia to Magallanes. Global Distribution: austral. (Grube \& Kantvilas 2006; Kantvilas 1986; Kantvilas \& Elix 2002).

\section{Parmelia cunninghamii Cromb.}

HABITAT ECOLOGY: an epiphyte of trees and shrubs in localities of high humidity. Records in Aisen: Jeinimeni, Tamango, Lago Riesco, Laguna San Rafael and on the roadside to Puerto Yungay. Distribution in Chile: Nuble Province to Magallanes and Antarctic Territory. Global Distribution: austral.

(Galloway 1985, 1992a).

\section{Parmelia protosulcata Hale}

Habitat ecology: an epiphyte of trees and shrubs in open sites, from sea level to $1100 \mathrm{~m}$ altitude. Records in Aisen: Jeinimeni, Tamango, Laguna San Rafael and on the roadside to Puerto Yungay. Distribution in Chile: Termas de Chillán (VIII Región) to Magallanes. Global DISTRIBUtion: austral. (Adler \& Calvelo 2002; Galloway 1985).

Parmelia saxatilis (L.) Ach.

HABITAT ECOLOGY: on rocks, rarely on tree trunks; frequent in steppe areas. RECORDS IN AISEN: Jeinimeni, Tamango and Laguna San Rafael. Distribution in Chile: La Campana National Park, and from Malleco Province to Isla Navarino and Antarctic Territory. GlobAL DISTRIBUTION: cosmopolitan.

(Øvstedal \& Lewis Smith 2001; Redón \& Quilhot 1977; Redón \& Walkowiak 1978).

\section{Parmelia sulcata Taylor}

Habitat ecology: an epiphyte of trees and shrubs from coastal to steppe areas.

ReCords in Aisen: Jeinimeni, Tamango and Laguna San Rafael. Distribution in Chile: Valparaíso to Isla Navarino and Antarctic Territory. Global DISTRIBUTION: cosmopolitan. (Øvstedal \& Lewis Smith 2001; Redón \& Quilhot 1977).

Parmeliella nigrocincta (Mont.) Müll. Arg.

Habitat ecology: an epiphyte of trees and shrubs in rainforests. ReCORDS IN AISEN: Valle Exploradores and Laguna San Rafael. Distribution in Chile: Juan Fernández Archipiélago, and from Malleco Province to Magallanes. Global Distribution: austral.

(Galloway 1985).

Parmeliopsis hyperopta (Ach.) Vain.

Habitat eCology: an epiphyte of trees and shrubs in open and moist forests. Records in Aisen: Tamango. Distribution in Chile: Rancagua to Magallanes. Global distribution: circumpolar.

(Ryan 2002b).

Parmotrema perlatum (Huds.) M. Choisy

Habitat ecology: an epiphyte on trees in open areas, occasionally on rocks. RECORDS IN Aisen: Tortel and Katalalixar. Distribution in Chile: Chillán to Magallanes. Global distribution: widespread in temperate regions of the Northern and Southern Hemispheres.

(Nash III \& Elix 2002b; Villagra et al. 2009).

Peltigera canina (L.) Willd.

Habitat eCology: on soil and amongst mosses in localities with high humidity. ReCords IN Aisen: Queulat, Isla Magdalena, on the roadside to Puerto Yungay and Katalalixar. Distribution in Chile: La Campana National Park to Magallanes. Global Distribution: circumpolar.

(Goward et al. 1995; Martínez et al. 2003; Redón \& Walkowiak 1978).

Peltigera collina (Ach.) Schrad.

HABITAT ECOLOGY: on soil and amongst mosses in steppe areas. Records in Aisen: Jeinimeni and Tamango. Distribution in Chile: Cautín Province to Magallanes. Global distribution: circumpolar.

(Goward et al. 1995; Martínez et al. 2003).

Peltigera didactyla (With.) J.R. Laundon

HABiTAT ECOlOGY: on soil, mosses and rotten wood in open sites. ReCords in Aisen: Valle Exploradores and Laguna San Rafael. Distribution in Chile: Zapahuira-Putre $(3400 \mathrm{~m}$ altitude), La Campana National Park, and from Los Queñes (VII Región) to Aisen and Antarctic Territory. Global DISTRIBUTION: cosmopolitan.

(Martínez et al. 2003; Redón \& Walkowiak 1978).

\section{Peltigera frigida $\mathrm{R}$. Sant.}

Habitat ecology: on soil in rainforests. Records in Aisen: Laguna San Rafael. Distribution in Chile: Valdivia to Magallanes. Global Distribution: the species is known in Tristán de Cuhna and southern Chile

(Martínez et al. 2003).

Peltigera lepidophora (Vain.) Bitter 
Habitat ECOlogy: on soil, amongst mosses and rotten wood in steppe areas. ReCORDS IN Aisen: Jeinimeni and Tamango. Distribution in Chile: Malleco Province to Magallanes. Global Distribution: circumpolar.

(Goward et al. 1995; Martínez et al. 2003).

\section{Peltigera membranacea (Ach.) Nyl.}

Habitat eCOlogy: on soil and amongst mosses ReCords in Aisen: Laguna San Rafael. Distribution in Chile: Aisen. Global DistRibution: cosmopolitan.

(Galloway 1992a; Goward et al. 1995).

Peltigera neckeri Hepp ex Müll. Arg.

Habitat ecology: on soil and mosses. Records in Aisen: Carretera Austral between Cochrane and Villa O'Higgins. Distribution in Chile: from Valdivia to Aisen and Antarctic Territory. Global DISTRIBUTION: bipolar (Øvstedal \& Lewis Smith 2001; UACH-UDEC 2007, 2008).

Peltigera polydacton (Neck.) Hoffm.

Habitat ecology: on soil and mosses. Records in Aisen: Laguna San Rafael and on the roadside to Puerto Yungay. Distribution in Chile: La Campana National Park, and from Aisen to Isla Navarino. Global Distribution: cosmopolitan.

(Martínez et al. 2003; Redón \& Quilhot 1977; Redón \& Walkowiak 1978).

Peltigera praetextata (Flörke ex Sommerf.) Zopf

Habitat ecology: on soil and mosses in habitats with high humidity. ReCords in Aisen: Laguna San Rafael. Distribution in Chile: Aisen. Global distribution: cosmopolitan.

(Galloway 1992a; Martínez et al. 2003).

\section{Peltigera pulverulenta (Taylor) Nyl.}

Habitat eCology: on soil and amongst mosses in localities with high humidity. Records in Aisen: Laguna San Rafael. Distribution in Chile: Valdivia to Magallanes. Global DISTRIBUTION: known in North and South America.

(Martínez et al. 2003).

Peltigera rufescens (Weiss) Humb.

Habitat ecology: on soil and amongst mosses. Records in Aisen: Laguna San Rafael. Distribution in Chile: Valdivia to Magallanes and Antarctic Territory. Global Distribution: cosmopolitan.

(Galloway 1992a; Martínez et. al. 2003; Øvstedal \& Lewis Smith 2001).

Peltigera scabrosa Th. Fr.

Habitat ecology: on soil. Records in Aisen: Jeinimeni, Tamango, Laguna San Rafael and the road to Puerto Yungay. Distribution in Chile: Valdivia to Magallanes. Global
DISTRIBUTION: pantropical.

(Galloway 1992a; Martínez et al. 2003).

Peltigera ulcerata Müll. Arg.

Habitat ecology: on soil and rotten wood in steppe areas. Records in Aisen: Tamango. Distribution in Chile: the species has been registered only in Aisen. Global DISTRIBUTION: cosmopolitan.

(Martínez et al. 2003).

Pertusaria dactylina (Ach.) Nyl.

HABITAT ECOLOGY: on the base of trunks in shrubs, on soil and mosses in steppe areas. RECORDS IN Aisen: Carretera Austral between Cochrane and Villa O'Higgins. Distribution in Chile: Chillán, and from Aisen to Magallanes. Global DISTRIBUTION: bipolar.

(Galloway 1985; UACH-UDEC 2007, 2008).

Pertusaria velata (Turner) Nyl.

Habitat eCOlogy: on bark of Nothofagus species, occasionally on rocks. ReCORDS in Aisen: Tamango and Tortel. Distribution IN Chile: Juan Fernandez Archipelago, Santiago and Rancagua, and from Cauquenes to Magallanes. Global Distribution: cosmopolitan.

(Messuti 2005).

Phaeographis patagonica Zahlbr.

Habitat ecology: on living bark of Nothofagus species in Valdivian rainforest. RECORDS IN Aisen: Valle Exploradores. Distribution in Chile: Aisen and Magallanes. Global Distribution: endemic to southern South America.

(Messuti \& Codesal 2009).

Phaeorrhiza nimbosa (Fr.) Mayrhofer \& Poelt HaBitat ECOlogy: on living trunks and in rock outcrops in temperate steppe areas. ReCords in Aisen: Dos Lagunas (Coyhaique) and Tamango. Distribution IN Chile: Aisen to Magallanes and Antarctic Territory. Global Distribution: bipolar.

(Elvebakk \& Moberg 2002; Øvstedal \& Lewis Smith 2001).

Phlyctis chilensis D.J. Galloway \& Guzmán

HABITAT ECOLOGY: on tree trunks in shady and moist habitats. Records in Aisen: Isla Magdalena, Dos Lagunas (Coyhaique), Jeinimeni, Valle Exploradores and Laguna San Rafael. Distribution in Chile: Los Queñes (VII Región) to Magallanes. Global Distribution: endemic to southern South America.

(Galloway \& Guzmán Grimaldi 1988).

Physcia adscendens (Fr.) H. Oliver

Habitat eCOlogy: an epiphyte on trunks and twigs of Nothofagus, also on rocks. Records in Aisen: Laguna San 
Rafael. Distribution in Chile: Valdivia to Magallanes. GLOBAL DISTRIBUTION: anfi-tropical.

(Elvebakk \& Moberg 2002).

Physcia caesia (Hoffm.) Fürnr.

HaBitat ECOlOGY: on rocks in steppe areas, from $800 \mathrm{~m}$ to $1400 \mathrm{~m}$ altitude. Records in Aisen: Jeinimeni and Tamango. Distribution in Chile: Putre, Portillo, San José de Maipo, Laguna del Maule, from Llanquihue to Isla Navarino and Antarctic Territory. GlobAL DISTRIBUTION: cosmopolitan. (Elvebakk \& Moberg 2002; Øvstedal \& Lewis Smith 2001; Redón \& Quilhot 1977).

Physconia muscigena (Ach.) Poelt

HABITAT ECOlOgy: on soil and mosses in steppe areas. RECORDS in Aisen: Tamango (1100 m altitude). Distribution in Chile: Putre, Portillo, and from Llanquihue to Isla Navarino and Antarctic Territory. Global Distribution: bipolar.

(Elvebakk \& Moberg 2002; Galloway 1998; Øvstedal \& Lewis Smith 2001).

Physconia perisidiosa (Erichs.) Moberg

HABitat ECOLOGY: on rocky slopes and walls, also on old living or fallen Nothofagus antarctica. RECORDS IN AISEN: Estancia Nirehuao and Tamango. Distribution in Chile: Aisen to Magallanes. GlobAl Distribution: cosmopolitan. (Elvebakk \& Moberg 2002).

\section{Placopsis baculigera I.M. Lamb}

HABITAT ECOLOGY: on coastal rocks, rock faces along roadsides. Records in Aisen: Laguna San Rafael. Distribution in Chile: Aisen to Magallanes. Global distribution: endemic to southern South America.

(Galloway 1992a, 2002, 2010).

Placopsis cribellans (Nyl.) Räsänen

HABITAT ECOLOGY: on rocks faces along roadsides. RECORDS in Aisen: Tamango. Distribution in Chile: Juan Fernández Archipiélago, and from Valdivia to Tierra del Fuego. GlobAL DISTRIBUTION: cosmopolitan.

(Galloway 1992a, 2002, 2007, 2010).

Placopsis fuscidula I.M. Lamb ex Räsänen

HABITAT ECOLOGY: from coastal rocks to alpine zones. RECORDS in Aisen: Tamango. Distribution in Chile: Juan Fernández Archipiélago, and from Volcán Antuco (VIII Región) to Isla Desolación (XII Región). Global Distribution: the species is known from Tristán de Cunha and Venezuela.

(Galloway 2002, 2007, 2010).

Placopsis lambii Hertel \& V. Wirth

HABitAT ECOlOGY: on acid rocks in open humid situations. Records in Aisen: Tamango. Distribution in Chile: Valdivia to Tierra del Fuego. Global distribution: cosmopolitan.
(Galloway 2002, 2007).

Placopsis parellina (Nyl.) I.M. Lamb

HABITAT ECOLOGY: on rocks from rather dry, disturbed habitats. Records in Aisen: Tamango. Distribution in CHILE: Juan Fernandez Archipelago and from Quillón (VIII Región) to Aisen. Global DISTRIBUTION: endemic to southern South America.

(Galloway 2002, 2010).

Placopsis perrugosa (Nyl.) Nyl.

HABITAT ECOLOGY: on gravelly soils and rocks. RECORDS IN Aisen: Tamango and Laguna San Rafael. Distribution IN Chile: Antuco to Aisen and Antarctic Territory. Global Distribution: austral, reaching as far north as Papua, New Guinea and New Ireland.

(Galloway 2002, 2007, 2010; Øvstedal \& Lewis Smith 2001).

\section{Placopsis pycnotheca I.M. Lamb}

HABITAT ECOLOGY: on gravelly soils and lava in recently deglaciated, riverine and volcanic environments. RECORDS in Aisen: Laguna San Rafael. Distribution in Chile: Juan Fernandez Archipelago and from Laguna de la Laja National Park to Magallanes. GlobAl Distribution: the species is known in southern South America from Chile (to VII to XII Regions) and Argentina.

(Galloway 1992a, 2002, 2010).

Placopsis stenophylla (Hue) I.M. Lamb

Habitat eCOLOGY: on small stones and pebbles and on old moraine surfaces, also coastal rocks. RECORDS IN Aisen: Laguna San Rafael and Fiordo Témpano. Distribution IN Chile: Lago Riñihue (Valdivia) to Magallanes. Global DISTRIBUTION: austral.

(Galloway 2002, 2007).

Placopsis subcribellans (I.M. Lamb) D.J. Galloway HABITAT ECOLOGY: on rocks and in coastal forests on hard, water worn, smooth rocks in heavily glaciated, high rainfall areas. Records in Aisen: Isla Magdalena. Distribution in Chile: Aisen to Magallanes. Global distribution: austral. (Galloway 2002, 2007, 2010).

\section{Placopsis tuberculifera (I.M. Lamb) Follmann}

Habitat eCOlogy: on sandy soil from sea level to $1800 \mathrm{~m}$ on both volcanic ash and on glacial moraines in alpine zones. Records in Aisen: Laguna San Rafael. Distribution in Chile: Volcán Osorno to Magallanes. Global Distribution: endemic to southern South America.

(Galloway 2002).

Platismatia glauca (L.) W.L. Culb. \& C.F. Culb. Habitat eCOlOgY: an epiphyte of trees and shrubs from sea 
level to $1100 \mathrm{~m}$. Records In Aisen: Jeinimeni, Tamango, Tortel. Distribution in Chile: La Campana National Park, and from Talca to Isla Navarino and Antarctic Territory. Global Distribution: cosmopolitan.

(Culberson \& Culberson 1968; Øvstedal \& Lewis Smith 2001; Redón \& Quilhot 1977).

\section{Polychidium contortum Henssen}

Habitat eCOlOGy: an epiphyte of trees and shrubs. RECORDS in Aisen: Laguna San Rafael. Distribution in Chile: the species has been registered only in Aisen. Global DISTRIBUTION: tropical.

(Galloway 1985, 1992a).

\section{Protousnea alectoroides (Mont.) Krog}

Habitat eCOlOGY: an epiphyte on bark of trees and shrubs in forest margins; from sea level to 1300. ReCORds in Aisen: Jeinimeni. Distribution in Chile: Nahuelbuta National Park to Aisen. Global distribution: endemic to southern South América.

(Calvelo et al. 2005; Krog 1976).

\section{Protousnea dusenii (D.R.) Krog}

HABITAT ECOLOGY: an epiphyte on tree trunks, rarely on shrubs and rocks; from sea level to $1300 \mathrm{~m}$, particularly in steppe areas. Records in Aisen: Carretera Austral near Cochrane and Jeinimeni. Distribution in Chile: Aisen to Isla Navarino. Global Distribution: endemic to southern South America. (Calvelo et al. 2005; Krog 1976).

\section{Protousnea magellanica (Mont.) Krog}

HABITAT ECOLOGY: an epiphyte on tree trunks and shrubs; from sea level more than $1300 \mathrm{~m}$. Together with $P$. malacea appears to be the commonest species in the genus. RECORDS IN AISEN: Carretera Austral between Balmaceda and Villa Cerro Castillo, Estancia Coyhaique, Estancia Ñirehuao, Coyhaique Alto, Mañihuales, Jeinimeni, Tamango and Puerto Bertrand. Distribution in Chile: Talca to Isla Navarino. Global DISTRIBUTION: endemic to southern South America

(Calvelo et al. 2005; Krog 1976; Redón \& Quilhot 1977).

\section{Protousnea malacea (Stirt.) Krog}

Habitat eCOlOgY: an epiphyte on tree trunks and shrubs; from sea level more than $1300 \mathrm{~m}$. Together with $P$. magellanica it appears to be the commonest species in the genus. Records in Aisen: Carretera Austral between Balmaceda and Villa Cerro Castillo, Mañihuales, Estancia Nirehuao, Estancia Coyhaique, Puerto Aisen, Río Simpson, Lago Riesco, Jeinimeni, Tamango, Chile Chico and Puerto Bertrand. Distribution in ChiLE: Talca to Isla Navarino. Global Distribution: endemic to southern South America. (Calvelo et al. 2005; Krog 1976; Redón \& Quilhot 1977).

Protousnea poeppigii (Nees \& Flot.) Krog
Habitat ECOlOGy: an epiphyte on tree trunks and shrubs, from sea level more than 1300m. RECORDS IN AisEn: Jeinimeni, Carretera Austral between Cochrane and Tortel. Distribution in Chile: Antuco to Magallanes. Global Distribution: endemic to southern South America. (Calvelo et al. 2005; Krog 1976).

\section{Protousnea teretiuscula Krog}

Habitat eCOlOGy: an epiphyte on tree trunks and shrubs; from sea level to $1300 \mathrm{~m}$. ReCORds IN Aisen: Jeinimeni, Tamango. Distribution in Chile: Nahuelbuta National Park to Aisen. Global Distribution: endemic to southern South America.

(Calvelo et al. 2005; Krog 1976).

\section{Pseudocyphellaria bartlettii D.J. Galloway}

Habitat eCOlOgY: an epiphyte on tree trunks and shrubs in Valdivian rainforest. Records in Aisen: Laguna San Rafael. Distribution in Chile: Fray Jorge National Park to Tierra del Fuego. Global Distribution: paleotropical; the species is known from Chile and Argentina, Ecuador, New Zealand and eastern Australia.

(Galloway 1992 a,b).

Pseudocyphellaria berberina (G. Forst.) D.J. Galloway \& P. James

Habitat ECOlOGY: an epiphyte on tree trunks and shrubs, on the ground and mosses; in very humid situations; from sea level to $1500 \mathrm{~m}$. Distribution in Aisen: Queulat, Isla Magdalena, Valle Exploradores, Laguna San Rafael, on the road to Puerto Yungay, Tortel and Katalalixar. Distribution IN Chile: Juan Fernández Archipiélago, and from Isla Mocha to Tierra del Fuego. Global Distribution: endemic to southern South America.

(Galloway 1992 a,b; Quilhot et al. 2010).

Pseudocyphellaria coerulescens (Mont.) H. Magn.

HABITAT ECOLOGY: an epiphyte on tree trunks and shrubs in rainforests. RECORDS IN Aisen: Queulat, Laguna San Rafael, Valle Exploradores and Katalalixar. Distribution in Chile: Juan Fernández Archipiélago, and from Isla Mocha to Tierra del Fuego. Global Distribution: endemic to southern South America.

(Galloway 1992 a,b; Quilhot et al. 2010).

\section{Pseudocyphellaria compar (Nyl.) H. Magn.}

Habitat ECOlOGY: an epiphyte on tree trunks and shrubs in Valdivian rainforest and in steppe areas. RECORDS IN Aisen: Jeinimeni, Tamango, Valle Exploradores and Laguna San Rafael. Distribution in Chile: Isla Mocha to Tierra del Fuego. Global Distribution: endemic to southern South America.

(Galloway 1992a,b; Quilhot et al. 2010). 
Pseudocyphellaria coriifolia (Müll. Arg.) Malme

HABITAT ECOLOGY: an epiphyte on tree trunks and shrubs in open forests in moderate to high light situations, from areas of high rainfall to dry grassland habitats. RECORDS IN AisEn: Isla Magdalena, Jeinimeni, Tamango, Valle Exploradores and Laguna San Rafael. Distribution IN Chile: Juan Fernández Archipiélago, and from Chillán to Isla Navarino. Global DISTRIBUTION: endemic to southern South America.

(Galloway 1992 a,b; Redón \& Quilhot 1977).

Pseudocyphellaria crocata (L.) Vain.

HABITAT ECOLOGY: an epiphyte of trees and shrubs, on soil and rocks, in a wide variety of habitats from sea level to 1500 m. Records in Aisen: Queulat, Isla Magdalena, Jeinimeni, Tamango, Estancia Ñirehuao, Valle Exploradores, Laguna San Rafael, Vagabundo and Tortel. Distribution in Chile: Juan Fernández Archipiélago, Fray Jorge National Park, and from Talca to Isla Navarino. Global Distribution: cosmopolitan.

(Galloway 1992a,b; Redón \& Quilhot 1977).

\section{Pseudocyphellaria dasyphyllidia Bjerke}

Habitat ECOlogy: an epiphyte of trees and shrubs in a wide variety of habitats, from 900 to $1400 \mathrm{~m}$ altitude. RECORDS in Aisen: Tamango. Distribution in Chile: Cauquenes to Magallanes. Global Distribution: endemic to southern South America.

(Bjerke et al. 2003b).

Pseudocyphellaria dissimilis (Nyl.) D.J. Galloway \& P. James

Habitat ecology: an epiphyte on tree trunks, in low light habitats. RECORDS IN AISEN: between Cochrane and Villa O'Higgins and Katalalixar. Distribution in Chile: Juan Fernández Archipiélago and Aisen. Global distribution: paleotropical.

(Galloway 1992a,b; UACH-UDEC 2007, 2008).

Pseudocyphellaria divulsa (Taylor) Imshaug

Habitat ecology: an epiphyte of trees and shrubs in dense forests, on mossy scrub and on coastal rocks in humid habitats. ReCords in Aisen: Queulat, Isla Magdalena, Tamango, Valle Exploradores, Laguna San Rafael, Vagabundo, Tortel and Katalalixar. Distribution in Chile: Malleco Province to Magallanes. Global distribution: endemic to southern South America.

(Galloway $1992 \mathrm{a}, \mathrm{b})$.

\section{Pseudocyphellaria dubia Du Reitz}

HABITAT ECOLOGY: an epiphyte of trees, among mosses and rocks, in deep shade habitats of high humidity. RECORDS IN AIsen: Jeinimeni, Tamango, Valle Exploradores and Laguna San Rafael. Distribution in ChiLE: Malleco Province to Isla Navarino. Global Distribution: endemic to southern South
America.

(Galloway 1992 a,b; Redón \& Quilhot 1977).

Pseudocyphellaria encoensis R. Sant.

Habitat ecology: an epiphyte of trees and shrubs in dense forests, in humid habitats. RECords in Aisen: Queulat, Isla Magdalena, Valle Exploradores, Laguna San Rafael, Tortel and Katalalixar. Distribution In Chile: Enco (X Región) to Magallanes. Global Distribution: paleotropical.

(Galloway 1992 a,b).

Pseudocyphellaria endochrysa (Delise) Vain.

HABitat ECOlOGY: on soil and moss-turf and in the lower parts of mossy tree trunks, from 900 to $1100 \mathrm{~m}$ altitude in steppe areas. Records IN Aisen: Laguna Tamanguito (Tamango). Distribution in Chile: Aisen to Isla Navarino. Global Distribution: endemic to southern South America.

(Galloway 1992 b; Redón \& Quilhot 1977).

\section{Pseudocyphellaria exanthematica I.M. Lamb}

Habitat ECOlogy: an epiphyte of forest trees in Valdivian rainforet, also on soil.

ReCORdS IN AISEN: Queulat and Laguna San Rafael. Distribution in Chile: Isla Mocha to Aisen. Global DISTRIBUTION: endemic to southern South America.

(Galloway 1992a,b; Quilhot et al. 2010).

Pseudocyphellaria faveolata (Delise) Malme

HaBitAT ECOLOGY: an epiphyte of forest trees in habitats in fairly open conditions with relatively high light intensity; from sea level to $1500 \mathrm{~m}$. Records IN Aisen: Queulat, Isla Magdalena, Valle Exploradores and Laguna San Rafael. Distribution in Chile: Nahuelbuta National Park to Tierra del Fuego. Global Distribution: pan-austral; also known in subantarctic islands, New Zealand and Tasmania.

(Galoway 1992a,b).

Pseudocyphellaria flavicans (Hook. \& Taylor) Vain.

HABITAT ECOLOGY: an epiphyte of forest trees in open and high-light habitats, from sea level to $1500 \mathrm{~m}$. RECORDS IN AIsEn: Queulat, Isla Magdalena, Valle Exploradores and Laguna San Rafael. Distribution IN Chile: Juan Fernández Archipiélago, and from Isla Mocha to Tierra del Fuego. Global Distribution: endemic to southern South America. (Galloway 1992 b; Quilhot et al. 2010).

Pseudocyphellaria freycinetii (Delise) Malme HABITAT ECOLOGY: a terricolous or muscicolous species found in subalpine habitats in steppe areas, from 600 to $1200 \mathrm{~m}$ altitude. Records in Aisen: Coyhaique, Cerros Divisaderos, Laguna Tamanguito (Tamango), Lago Presidente Ríos and Península de Taitao. Distribution in Chile: Juan Fernández Archipiélago, and from Puyehue to Isla Navarino. Global DISTRIBUTION: endemic to southern South America. 
(Galloway 1992 a,b; Redón \& Quilhot 1977).

Pseudocyphellaria gilva (Ach.) Malme

HABITAT ECOLOGY: on coastal rocks, on living and dead wood of trees and shrubs in open forest areas. RECORDS IN Aisen: Tamango and Laguna San Rafael. Distribution in Chile: Juan Fernández Archipiélago, and from Constitución to Magallanes. GlobAL DISTRIBUTION: paleotropical.

(Galloway 1992 b).

Pseudocyphellaria glabra (Hook. f. \& Taylor) C.W. Dodge HABITAT ECOLOGY: on rocks, living and dead vegetation at sea level; lowland forests, scrub and mooreland or grasland associations, to subalpine and high alpine scrub. RECORDS In Aisen: Queulat, Valle Exploradores, Laguna San Rafael, Vagabundo and Katalalixar. Distribution in Chile: Juan Fernández Archipiélago, Isla Mocha to Tierra del Fuego. Global Distribution: panaustral.

(Galloway 1992 a,b; Quilhot et al. 2010).

Pseudocyphellaria granulata (C. Bab.) Malme

HABITAT ECOlOGY: an epiphyte of forest trees in fairly open conditions with relatively high light intensity; from sea level to $1300 \mathrm{~m}$. Records in Aisen: Tamango and Valle Exploradores. Distribution IN Chile: Nahuelbuta National Park to Isla Navarino.

GLOBAL DISTRIBUTION: austral.

(Galloway 1992 a,b; Redón \& Quilhot 1977).

Pseudocyphellaria guillemini (Mont.) D.J. Galloway

Habitat eCology: an epiphyte of trees and shrubs in rainforests in rather low light situations. RECORDS IN AISEN: Laguna San Rafael. Distribution in ChiLE: Juan Fernández Archipiélago, Conguillio National Park to Magallanes. Global Distribution: endemic to southern South America. (Galloway 1992 b).

Pseudocyphellaria hillii (C.W. Dodge) D.J. Galloway HABITAT ECOLOGY: an epiphyte of trees and shrubs particularly in forest margin, on soil or among mosses, on open grassland. Records in Aisen: Tamango. Distribution in Chile: Aisen to Magallanes. Global Distribution: endemic to southern South America.

(Galloway 1992b).

\section{Pseudocyphellaria hirsuta (Mont.) Malme}

HABITAT ECOLOGY: an epiphyte of trees and shrubs particularly in forest margin, on soil and rocks in a wide range of humidity, from sea level to $1500 \mathrm{~m}$. RECORDS in AIsen: Queula, Jeinimeni, Tamango, Valle Exploradores, Laguna San Rafael and on the road to Puerto Yungay Distribution IN CHILE: Juan Fernández Archipiélago, and from Constitución to Tierra del Fuego. Global Distribution: endemic to southern South America.
(Galloway 1992b).

Pseudocyphellaria intricata (Delise) Vain.

HABITAT ECOlOGY: an epiphyte of trees and shrubs in humid rainforests in moderate to dense shade. RECORDS IN Aisen: Queulat, Isla Magdalena, Valle Exploradores, Laguna San Rafael, Vagabundo, Tortel and Katalalixar. Distribution IN Chile: Juan Fernández Archipiélago, Fray Jorge National Park to Tierra del Fuego. Global Distribution: cosmopolitan.

(Galloway 1992 a,b).

Pseudocyphellaria lechleri (Müll. Arg.) Du Rietz

Habitat eCOlogy: an epiphyte of trees and shrubs, on the ground among mosses, in alpine and subalpine habitats. ReCords in Aisen: Tamango (1000 m altitude). Distribution IN Chile: Conguillio National Park to Tierra del Fuego. Global distribution: endemic to southern South America.

(Galloway 1992b; Redón \& Quilhot 1977).

Pseudocyphellaria mallota (Tuck.) H. Magn.

HABITAT ECOLOGY: an epiphyte of trees and shrubs in Valdivian rainforest and steppe areas, on rocks and stumps in open forests or on deforested slopes, in humid and moderate light situations. ReCords in AIsEn: Jeinimeni, Tamango, Valle Exploradores and Laguna San Rafael. Distribution IN ChiLE: Juan Fernández Archipiélago, Fray Jorge National Park, and from Valdivia to Magallanes. Global Distribution: endemic to southern South America

(Galloway 1992a,b).

\section{Pseudocyphellaria malmeana D.J. Galloway}

Habitat ECOlOgy: an epiphyte of trees and shrubs in Valdivian rainforest, on rocks and stumps in open forests or on deforested slopes in humid and shaded habitats. ReCORDS IN Aisen: Queulat, Carretera Austral south of Cochrane. Distribution in Chile: Isla Mocha to Aisen. Global DISTRIBUTION: endemic to southern South America.

(Galloway 1992a,b; Quilhot et al. 2010).

Pseudocyphellaria meyenii (Trevis.) D.J. Galloway

HABitat ECOLOGY: an epiphyte of trees and shrubs in lowland to montane Valdivian rainforest, having an altitudinal range from sea level to $800 \mathrm{~m}$. RECORDS In AisEn: Valle Exploradores and Laguna San Rafael. Distribution in Chile: Isla Mocha to Aisen. Global Distribution: endemic to southern South America.

(Galloway 1992 a,b; Quilhot et al. 2010).

Pseudocyphellaria neglecta (Müll. Arg.) H. Magn.

HABITAT ECOLOGY: an epiphyte of trees and shrubs, on rocks in dryish habitats with a high light intensisty. RECORDS IN Aisen: Jeinimeni, Coyhaique Bajo, Estancia Nirehuao and Río Simpson. Distribution in Chile: la Campana National 
Park to Tierra del Fuego. Global distribution: austral. (Galloway 1992b).

\section{Pseudocyphellaria nitida (Taylor) Malme}

HABitat eCology: an epiphyte of trees and shrubs in Valdivian rainforest in moderate to high-light habitats of high rainfall, with an altitudinal range from sea level to $1600 \mathrm{~m}$. ReCORDS IN Aisen: Queulat, Río Cisnes, Valle Exploradores, Laguna San Rafael, Tortel and Katalalixar. Distribution IN CHILE: Juan Fernández Archipiélago, and from Nahuelbuta National Park to Magallanes. Global Distribution: endemic to southern South America.

(Galloway 1992b).

Pseudocyphellaria norvegica (Gyeln.) P. James

HABitat ECOlOGY: an epiphyte of trees and shrubs in humid habitats. Records in Aisen: Tamango and Laguna San Rafael. Distribution in Chile: Juan Fernández Archipiélago, and from Isla Mocha to Aisen. Global Distribution: cosmopolitan.

(Galloway 1992a,b; Quilhot et al. 2010).

Pseudocyphellaria nudata (Zahlbr.) D.J. Galloway HaBitat ECOLOGY: an epiphyte of trees and shrubs in forested areas, mainly in rather drier and moderate to high light situations. ReCords In Aisen: Tamango, Valle Exploradores and Laguna San Rafael. Distribution in Chile: Chillán to Aisen. Global distribution: endemic to southern South America.

(Galloway 1992b).

Pseudocyphellaria obvoluta (Ach.) Malme

HABitat ECOlOGy: an epiphyte of trees and shrubs, also on rocks in lowland and subalpine forests in areas of high rainfall; from sea level to $1500 \mathrm{~m}$. ReCORds IN Aisen: Puerto Bertrand and Vagabundo. Distribution in Chile: Nahuelbuta National Park to Isla Navarino. Global DISTRIBUtion: endemic to southern South America.

(Galloway 1992 b; Redón \& Quilhot 1977).

\section{Pseudocyphellaria pilosella Malme}

HABitat ECOlOGY: an epiphyte of trees and shrubs in moist humid, rather low-light habitats. ReCORDS IN Aisen: Queulat, Tamango, Valle Exploradores, Laguna San Rafael and Lago Presidente Ríos. Distribution in Chile: Chillán to Aisen. Global Distribution: endemic to southern South America. (Galloway $1992 \mathrm{a}, \mathrm{b}$ ).

Pseudocyphellaria piloselloides (Räsänen) H. Magn. Habitat ECOlOgy: an epiphyte of trees and shrubs in open forests. Records in Aisen: Queulat, Valle Exploradores and Laguna San Rafael. Distribution in Chile: Conguillio National Park to Tierra del Fuego. Global distribution: endemic to southern South America.
(Galloway 1992 a,b).

Pseudocyphellaria pluvialis R. Sant.

Habitat ECOlOGY: an epiphyte of trees and shrubs in very humid, often deeply shaded situations. ReCords in Aisen: Valle Exploradores and Laguna San Rafael. Distribution IN Chile: Isla Mocha to Aisen. Global Distribution: endemic to southern South America.

(Galloway 1992 a,b; Quilhot et al. 2010).

Pseudocyphellaria redonii D.J. Galloway

HABiTAT ECOLOGY: an epiphyte of trees and shrubs, rarely on rocks; in shaded, humid habitats from sea level to 1000 m. Records in Aisen: Laguna San Rafael. Distribution in Chile: Cautín Province to Magallanes. Global Distribution: endemic to southern South America.

(Galloway 1992a, b).

Pseudocyphellaria santessonii D.J. Galloway

Habitat eCOlOgy: an epiphyte of trees and shrubs in mixed humid rainforest, in habitats of moderate light. RECORDS IN Aisen: Península de Taitao and Lago Presidente Ríos. Distribution in Chile: Juan Fernández Archipiélago, and from Isla Mocha to Magallanes. Global Distribution: endemic to southern South America.

(Galloway 1992a,b; Quilhot et al. 2010).

Pseudocyphellaria scabrosa R. Sant.

Habitat eCOlOgy: an epiphyte of trees and shrubs in rainforests in low-light intensities, from sea level to 1500 m. Records in Aisen: Queulat, Valle Exploradores, Laguna San Rafael, Vagabundo. Distribution in Chile: Isla Mocha to Isla Navarino. Global Distribution: endemic to southern South America.

(Galloway 1992a,b; Quilhot et al. 2010; Redón \& Quilhot 1977).

\section{Pseudocyphellaria subrubella Räsänen}

HABITAT ECOLOGY: an epiphyte of trees and shrubs in conditions of moderate light between altitudes $500-1600 \mathrm{~m}$. Records in Aisen: Puerto Bertrand. Distribution in Chile: Llanquihue to Aisen. Global distribution: endemic to southern South America.

(Galloway 1992a,b).

\section{Pseudocyphellaria vaccina (Mont.) Malme}

Habitat ECOlOgY: an epiphyte of trees and shrubs, in open forests near the margins and at treeline. ReCORDS IN AisEN: Laguna San Rafael and Vagabundo. Distribution in Chile: Isla Mocha to Tierra del Fuego. Global distribution: endemic to southern South America.

(Galloway 1992b; Quilhot et al. 2010).

\section{Pseudocyphellaria valdiviana (Nyl.) Follmann}


Habitat eCOlOgy: an epiphyte of trees and shrubs in Valdivian rainforest, among ferns and mosses in fairly open conditions. Records IN Aisen: Laguna San Rafael and Vagabundo. Distribution in Chile: Temuco to Aisen. Global Distribution: endemic to southern South America. (Galloway 1992a,b).

\section{Pseudocyphellaria wandae D.J. Galloway}

HABitat ECOLOGY: an epiphyte of trees and shrubs in humid, high rainfall habitats in moderate shade from 100 to $1000 \mathrm{~m}$ altitude. Records in Aisen: Isla Magdalena. Distribution in Chile: Constitución to Aisen. Global distribution: endemic to southern South America.

(Galloway 1992b).

\section{Psoroma cinnamomeum Malme}

Habitat ecology: on soil and mosses in habitats with high humidity. Records in Aisen: Tamango and Laguna San Rafael. Distribution in Chile: Aisen to Tierra del Fuego and Antarctic Territory. Global distribution: the species is known in southern South America and Antarctica.

(Galloway 1992a; Henssen \& Renner 1981; Øvstedal \& Lewis Smith 2001).

Psoroma echinaceum P.M. Jørg. \& Wedin

HaBitAT ECOLOGY: an epiphyte of tree trunks in habitats with high humidity. Records in Aisen: Laguna San Rafael. Distribution in Chile: the species in known only in Aisen and southern Argentina. Global Distribution: endemic to southern South America.

(Jørgensen \& Wedin 1999).

\section{Psoroma fruticulosum P. James \& Henssen}

HaBitAT ECOlOGy: an epiphyte on twigs and small branches of trees and shrubs, also on soil in humid and shaded habitats. Records in Aisen: Queulat and Tamango. Distribution in Chile: Conguillio National Park to Magallanes and Antarctic Territory. Global DistRiBution: known from South America, Subantarctic Islands, New Zealand and South Africa.

(Jørgensen \& Galloway 1992; Øvstedal \& Lewis Smith 2001).

\section{Psoroma hypnorum (Vahl) S.F.Gray}

HABitat ECOlOGY: an epiphyte of trees and shrubs, on soil and mosses in steppe areas. ReCords in Aisen: Jeinimeni and Tamango. Distribution in Chile: from Isla Mocha to Magallanes and Antarctic Territory. Global Distribution: bipolar.

(Øvstedal \& Lewis Smith 2001; Quilhot et al. 2010).

Psoroma palaceum (Fr.) Timbal \& Tønsberg

Habitat eCOlOgy: on mosses and rotten wood in humid and shaded habitats in steppe areas. ReCORDS in Aisen: Jeinimeni (950 m altitude). Distribution IN Chile: Aisen and
Magallanes. Global DistRibUtion: bipolar.

(Timdal \& Tønsberg 2006).

Psoroma tenue Henssen

Habitat ecology: on mosses, rocks and soil. ReCords in Aisen: Jeinimeni and Tamango. Distribution in Chile: Aisen to Isla Navarino and Antarctic Territory. Global DistRiBution: the species is known in southernmost South America and in Antarctica.

(Henssen \& Renner 1981; Øvstedal \& Lewis Smith 2001).

Psorophorus pholidotus (Mont.) Elvebakk

HaBitat ECOlogy: an epiphyte on trees and shrubs in humid and shaded habitats. RECORDS IN Aisen: Queulat and Tortel. Distribution in Chile: Juan Fernández Archipiélago, and from Conguillio National Park to Magallanes. GlobaL DISTRIBUTION: austral.

(Elvebakk et al. 2010).

\section{Punctelia borreri (Sm.) Krog}

Habitat eCOlogy: on the bark of trees and shrubs in rather shaded bitats. ReCords in Aisen: Carretera Austral between Cochrane and Villa O'Higgins. Distribution in Chile: Isla Mocha, and from Valdivia to Magallanes. GLOBAL DISTRIBUTION: cosmopolitan.

(Galloway 1985, UACH-UDEC 2007, 2008)

Rhizocarpon geographicum (L.) DC.

Habitat ecology: on rocks in open sites. Records in Aisen: Jeinimeni and Tamango. Distribution in Chile: Juan Fernández Archipiélago, and from Portillo to Isla Navarino and Antarctic Territory. Global Distribution: cosmopolitan.

(Øvstedal \& Lewis Smith 2001, Redón \& Quilhot 1977).

Rhizocarpon grande (Flörke) Arnold

HABitAT ECOlOgY: on rocks in open sites. ReCORds IN Aisen: Jeinimeni, Tamango. Distribution in Chile: Aisen to Magallanes and Antarctic Territory. Global Distribution: bipolar.

(Galloway 2007; Øvstedal \& Lewis Smith 2001).

Rhizoplaca aspidophora (Vain.) Redón

Habitat ecology: on rocks in open sites. Records in Aisen: Jeinimeni and Tamango (800-1000 m). Distribution in ChiLe: Chucuyo (northern Altiplano, $4500 \mathrm{~m}$ ), Portillo (2600 $\mathrm{m})$, San José de Maipo (900-2400 m), Laguna del Maule $(2540 \mathrm{~m}$ ), and from Aisen to Magallanes and Antarctic Territory. GLOBAL DISTRIBUTION: southern South America and Antarctica.

(Øvstedal \& Lewis Smith 2001; Quilhot et al. 2007).

Rhizoplaca chrysoleuca (Sm.) Zopf

Habitat ecology: on rocks, also on soil in open sites in 
alpine zones. RECORDS IN Aisen: Jeinimeni (900 m altitude). Distribution IN Chile: Chucuyo (northern Altiplano, $4500 \mathrm{~m}$ ) to Trapa-Trapa (VIII Región) and Aisen. GlobAL DISTRIBUTION: circumarctic, circumboreal to warmtemperate.

(Quilhot et al. 2007; Ryan 2002c).

Rhizoplaca melanophthalma (Ramond) Leuckert \& Poelt HABITAT ECOLOGY: on rocks in alpine areas, usually in open sites. ReCORdS IN Aisen: Jeinimeni and Tamango (800$1200 \mathrm{~m}$ altitude). Distribution In Chile: Putre to Chungará (Altiplano, 3500 to 4600 m), Portillo (2680 m), La Campana National Park (1910 m), San José de Maipo (900-2400 m), Laguna del Maule $(2540 \mathrm{~m})$, from Aisen to Magallanes and Antarctic Territory. GlobAl Distribution: bipolar, circumboreal, extending to the tropics in alpine areas (Øvstedal \& Lewis Smith 2001; Quilhot et al. 2007; Redón \& Walkowiak 1978; Ryan 2002c).

\section{Rimelia reticulata (Taylor) Hale \& A. Flechter}

HABITAT ECOLOGY: an epiphyte of trees occurring in a wide variety of habitats, also on rocks in exposed situations. Records in Aisen: Tamango. Distribution in Chile: Talca to Aisen. Global Distribution: cosmopolitan, widespread throughout the tropics and temperate areas.

(Louwhoff \& Elix 2002; Nash III \& Elix 2002c).

Rinodina olivaceobrunnea C.W. Dodge \& G.E. Baker Habitat ecology: on rocks in open sites. Records in Aisen: Tamango. Distribution in Chile: from Aisen to Magallanes and Antarctic Territory. Global Distribution: bipolar. (Jacobsen \& Kappen 1989; Øvstedal \& Lewis Smith 2001).

\section{Rusavskia elegans (Link) S.Y. Kondr. \& Kärnefelt}

Habitat ecology: on rocks in open sites. Records in Aisen: Jeinimeni. Distribution IN Chile: Putre, Juan Fernández Archipiélago, La Campana National Park, from Laguna de la Laja National Park to Isla Navarino and Antarctic Territory. GlobAl DisTRIBUtion: bipolar.

(Fedorenko et al. 2009; Øvstedal \& Lewis Smith 2001; Redón \& Quilhot 1977; Redón \& Walkowiak 1978).

Sphaerophorus globosus (Huds.) Vain.

Habitat ECOlOGy: on soil, among mosses in open sites. Records in Aisen: Tamango and Laguna San Rafael. Distribution in Chile: from Llanquihue to Isla Navarino and Antarctic Territory. Global Distribution: bipolar.

(Galloway 1992a; Øvstedal \& Lewis Smith 2001; Redón \& Quilhot 1977; Wedin 1995).

\section{Stereocaulon alpinum Laurer}

Habitat ecology: on rocks and mosses in open sites. Records in Aisen: Tamango (900-1100 m). Distribution in Chile: from Cautín Province to Isla Navarino and Antarctic
Territory. GlobAl DistRIBUTION: bipolar.

(Lamb 1977; Øvstedal \& Lewis Smith 2001; Redón \& Quilhot 1977)

\section{Stereocaulon corticatulum Nyl.}

Habitat eCOlogy: on mosses and rocks in open sites. Records in Aisen: Tamango. Distribution in Chile: Cerro Moreno (Antofagasta), and from Laguna de la Laja National Park to Magallanes. Global Distribution: austral.

(Follmann 1967; Lamb 1977; Redón 1974).

Stereocaulon glabrum (Müll. Arg.) Vain.

HABITAT ECOlOGY: on rocks, often amongst mosses. RECORDS in Aisen: Tamango. Distribution in Chile: Nahuelbuta National Park to Magallanes and Antarctic Territory. Global Distribution: southernmost South America, Tristán de Cunha and Antarctica.

(Lamb 1977; Øvstedal \& Lewis Smith 2001).

Stereocaulon implexum Th. Fr.

Habitat ECOlOGY: on rocks and soil in open sites. RECORDS IN Aisen: Laguna San Rafael. Distribution in Chile: Laguna de la Laja National Park to Magallanes. GlobAL Distribution: austral.

(Lamb 1977).

Stereocaulon ramulosum (Sw.) Räusch.

Habitat ecology: on soil, rocks and mosses.Records IN Aisen: Carretera Austral, Queulat, Isla Magdalena, Jeinimeni, Tamango, Valle Exploradores, Laguna San Rafael and Tortel. Distribution in Chile: Talca to Magallanes and Antarctic Territory. GlobAl Distribution: cosmopolitan. (Galloway 1985; Øvstedal \& Lewis Smith 2001).

\section{Stereocaulon tomentosum Fr.}

Habitat ecology: on rocks. Records in Aisen: Laguna San Rafael. Distribution in CHILE: from Valdivia to Magallanes. GLOBAL DisTRIBUTION: circumpolar.

(Goward \& Ahti 1992).

Stereocaulon vesuvianum Pers.

Habitat ecology: on rocks and soil. Records in Aisen: Tamango. Distribution in Chile: Antuco to Magallanes and Antarctic Territory. Global distribution: cosmopolitan. (Galloway 1985; Øvstedal \& Lewis Smith 2001).

\section{Sticta ainoae D.J. Galloway \& J. Pickering}

HABITAT ECOLOGY: an epiphyte of forest trees and shrubs in humid, rather shaded habitats in Valdivian rainforest, also amongst mosses. RECORDS IN Aisen: Queulat, Isla Magdalena, Rio Cisnes, Valle Exploradores and Laguna San Rafael. Distribution in Chile: Isla Mocha to Aisen. Global Distribution: endemic to southern South America.

(Galloway 1992a; 1994; Quilhot et al. 2010). 
Sticta caulescens De Not.

HABITAT ECOLOGY: an epiphyte of rainforest trees and shrubs, also on soil in very humid and often deeply shaded habitats. Records in Aisen: Isla Magdalena, Vagabundo, Valle Exploradores, Laguna San Rafael, on the roadside to Puerto Yungay and Katalalixar. Distribution in Chile: Isla Mocha to Magallanes. Global Distribution: endemic to southern South America.

(Galloway 1994; Quilhot et al. 2010).

Sticta fuliginosa (Hoffm.) Ach.

HABITAT ECOLOGY: an epiphyte of bark and twigs of trees and shrubs in rather drier habitats. ReCORDS IN AISEN: Carretera Austral between Chaitén and Lago Yelcho, Queulat, Jeinimeni, Tamango, Laguna San Rafael, Valle Exploradores and Tortel. Distribution in Chile: Putre, and from Fray Jorge National Park to Magallanes. Global distribution: cosmopolitan.

(Herrera pers. comm.; Galloway 1992a, 1994).

\section{Sticta gaudichaldia Delise}

HABITAT ECOLOGY: on soil and sandy soils, amongst mosses in rainforests. RECORDS IN Aisen: Laguna San Rafael. Distribution in Chile: Puyehue to Tierra del Fuego. Global DISTRIBUTION: endemic to southern South America.

(Galloway 1992a, 1994).

Sticta hypochra Vain.

Habitat eCOlogy: an epiphyte of trees and shrubs in rainforests, on stones and amongst mosses and rotten wood. Records in Aisen: Jeinimeni, Tamango and Laguna San Rafael, Tortel and Katalalixar. Distribution in Chile: from Conguillio National Park to Isla Navarino. Global DISTRIBUTION: endemic to southern South America.

(Galloway 1994; Redón \& Quilhot 1977).

Sticta limbata (Sm.) Ach.

HaBitat eCOlOgY: an epiphyte on twigs in understory vegetation in Valdivian rainforest. RECORDS IN AISEN: Laguna San Rafael. Distribution in Chile: Isla Mocha to Tierra del Fuego. Global distribution: cosmopolitan.

(Galloway 1992a, 1994).

\section{Sticta longipes (Müll. Arg.) Malme}

HABITAT ECOlOGY: an epiphyte in Valdivian rainforests in low-light situations and high humidity. RECORDS IN Aisen: Queulat and Laguna San Rafael. Distribution In Chile: Isla Mocha to Aisen. Global Distribution: endemic to southern South America.

(Galloway 1994; Quilhot et al. 2010).

Sticta santessonii D.J. Galloway

HABITAT ECOLOGY: a primarily terricolous species in low heathland vegetation, among mosses in situations of high humidity. Records in Aisen: Queulat and Laguna San Rafael. Distribution in Chile: Conguillio National Park to Magallanes. Global Distribution: endemic to southern South America.

(Galloway 1994).

Sticta sublimbata (J. Steiner) Swinscow \& Krog

HABitAT ECOlogy: from bark of forest trees in open to moderately shaded habitats. RECORDS IN AISEN: Carretera Austral near Chaitén, Puerto Aisen and Laguna San Rafael. Distribution in Chile: Isla Mocha, and from Puyehue to Aisen. Global Distribution: paleotropical.

(Galloway 1992a, 1994; Quilhot et al. 2010).

Sticta weigelii (Ach.) Vain.

HABITAT ECOLOGY: on tree trunks and shrubs, on soil in fairly open habitats in areas of high humidity; from sea level up to $1500 \mathrm{~m}$. Records in Aisen: Queulat and Laguna San Rafael. Distribution in Chile: Fray Jorge National Park, and from Conguillio National Park to Isla Navarino. GLOBAL DISTRIBUTION: paleotropical.

(Galloway 1992a, 1994, 2006; Redón \& Quilhot 1977).

Tapellaria epiphylla (Müll. Arg.) R. Sant.

HABITAT ECOLOGY: on tree bark and living leaves, in rainforests. Records in Aisen: Laguna San Rafael. Distribution in Chile: from Valdivia to Magallanes. Global distribution: pantropical

(Lücking et al. 2003).

Tephromela atra (Huds.) Hafellner

Habitat ecology: On tree bark and rocks. Records in Aisen: Jeinimeni and Tamango. Distribution in Chile: Zapahuira (3200 m), Juan Fernández Archipiélago, and from Valparaíso to Isla Navarino and Antarctic Territory. GLOBAL DISTRIBUTION: cosmopolitan

(Galloway 1998; Øvstedal \& Lewis Smith 2001; Redón \& Quilhot 1977).

Thamnolia vermicularis (Sw.) Ach. ex Schaer.

Habitat ecology: on soil and mosses. Records in Aisen: Tamango and Tortel. Distribution IN Chile: Valdivia to Isla Navarino. GlobAl DistRIBUtion: bipolar.

(Galloway 1985, 2007; Redón \& Quilhot 1977).

\section{Thelotrema lepadinum (Ach.) Ach.}

HABitat ECOLOGY: an epiphyte of trees and shrubs. RECORDS IN Aisen: Valle Exploradores and Laguna San Rafael. Distribution in Chile: Coquimbo, Juan Fernández Archipiélago, and from Concepción to Magallanes. GLOBAL DISTRIBUTION: cosmopolitan.

(Galloway 1985). 
Toninia bullata (Meyen \& Flot) Zahlbr.

Habitat ecology: On rocks in open sites. Records in Aisen: Tamango and Jeinimeni (800 to $1100 \mathrm{~m}$ ). Distribution in Chile: Putre (3350 m), and from Laguna del Maule (2500 m) to Aisen. Global Distribution: austral. (Galloway 1985, 1998).

\section{Toninia sedifolia (Scop.) Timdal}

HABitat ECOlOgY: on soil and rocks in alpine zones. ReCORDS in Aisen: Tamango. Distribution in Chile: Laguna del Maule, from Aisen to Magallanes. Global Distribution: cosmopolitan.

(Timdal 2002).

Tukermannopsis chlorophylla (Willd.) Hale

HABITAT ECOLOGY: an epiphyte in living trunks in rather drier habitats. RECORDS IN Aisen: Jeinimeni, Tamango and Vagabundo. Distribution in Chile: La Campana National Park to Magallanes. Global Distribution: bipolar. (Kärnefelt et al. 1992).

Umbilicaria antarctica Frey \& I.M. Lamb

HABITAT ECOLOGY: on rocks in alpine areas. ReCORdS In Aisen: Jeinimeni and Tamango (1100 m elevation). DistRIBUTION IN Chile: Aisen, Magallanes and Antarctic Territory. Global DISTRIBUTION: east of Spain, South America, Antarctica.

(Øvstedal \& Lewis Smith 2001).

Umbilicaria cylindrica (L.) Del.

Habitat ecology: on rocks in steppe areas. ReCORDS IN Aisen: Jeinimeni and Tamango. Distribution in Chile: from Llanquihue to Magallanes. Global Distribution: cosmopolitan.

(Galloway 1985, 2007).

Umbilicaria decussata (Vill.) Zahlbr.

Habitat ECOlogy: on rocks in steppe areas. Records in Aisen: Jeinimeni. Distribution in Chile: Portillo, Laguna del Maule, and from Llanquihue to Magallanes and Antarctic Territory. Global Distribution: cosmopolitan.

(Galloway 2007; Øvstedal \& Lewis Smith 2001; Sancho et al. 1992).

Umbilicaria nylanderiana (Zahlbr.) H. Magn.

HABitat eCOlOgY: on rocks in steppe areas. ReCORDS in Aisen: Chile Chico and Fachinal. Distribution in Chile: from Osorno to Magallanes and Antarctic Territory. GlobaL DISTRIBUTION: bipolar.

(Galloway 2007; Øvstedal \& Lewis Smith 2001; Sancho et al. 1992).

Umbilicaria polyrrhiza (L.) Fr.

HABITAT ECOLOGY: on rocks in open sites in steppe areas. ReCords in Aisen: Chile Chico and Carretera Austral between
Cochrane and Villa O'Higgins. Distribution in Chile: Laguna del Maule to Magallanes. Global distribution: cosmopolitan.

(Crespo \& Sancho 1978; UACH-UDEC 2007, 2008).

\section{Usnea acromelana Stirt.}

Habitat ecology: on rocks and soil in open sites. Records in Aisen: Jeinimeni and Tamango. Distribution in Chile: Llanquihue to Isla Navarino and Antarctic Territory. GLOBAL DISTRIBUTION: austral.

(Øvstedal \& Lewis Smith 2001; Wirtz 2006; Wirtz et al. 2008).

Usnea aurantiaco-atra (Jacq.) Bory

Habitat ecology: on rocks in open sites. Records in Aisen: Tamango. Distribution IN ChiLE: Llanquihue to Isla Navarino and Antarctic Territory. Global Distribution: southernmost South America and Antarctica.

(Øvstedal \& Lewis Smith 2001; Redón 1974; Redón \& Quilhot 1977; Wirtz 2006; Wirtz et al. 2008).

\section{Usnea cornuta Körb.}

HABITAT ECOLOGY: on wood, bark and rocks, usually in well open situations. RECORDS IN AISEN: on the road side between Cochrane and Villa O'Higgins. Distribution In CHILE: Aisen. GLOBAL DISTRIBUTION: cosmopolitan.

(Fos \& Clerc 2000; UACH-UDEC 2007, 2008).

Usnea trachycarpa (Stirt.) Müll. Arg.

Habitat ecology: on rocks in open sites. Records in Aisen: Tamango. Distribution IN ChiLE: Llanquihue to Isla Navarino and Antarctic Territory. Global distribution: endemic to southern South America.

(Øvstedal \& Lewis Smith 2001; Redón 1974; Redón \& Quilhot 1977; Wirtz 2006; Wirtz et al. 2008).

Verrucaruia maura Wahlenb.

Habitat eCOlogy: on coastal rocks. ReCords in Aisen: Laguna San Rafael. Distribution IN Chile: Llanquihue to Isla Navarino and Antarctic Terrritory. Global DISTRIBUtion: cosmopolitan.

(Galloway 1922a; Øvstedal \& Lewis Smith 2001; Redón \& Quilhot 1977).

Xanthoparmelia ulcerosa (Zahlbr.) Hale

Habitat ecology: on rocks in open sites. Records in Aisen: Estancia Nirehuao, Coyhaique. Distribution IN Chile: Valparaíso and Santiago, from Aisen to Magallanes. GlobaL DISTRIBUTION: the species is apparently restringed to South America.

(Nash III et al. 1995).

Xanthopsoroma contextum (Stirt.) Elvebakk

HaBitat ECOlOGy: an epiphyte of trees and shrubs, also on mosses in habitats of high humidity. ReCORDS IN Aisen: 
Queulat, Puerto Cisnes, Puerto Aisen, Valle Exploradores and Carretera Austral 38 km north of Bahía Murta. Distribution IN Chile: Juan Fernández Archipiélago, and from Malleco Province to Magallanes. GlobAL DISTRIBUTION: austral. (Elvebakk et al. 2010).

Xanthopsoroma soccatum (R. Br. ex Cromb.) Elvebakk Habitat eCOlOgY: on twigs of shrubs and trees, also on mosses. Records in Aisen: Puerto Aisen, Lago Las Torres and Laguna San Rafael. Distribution in Chile: Juan Fernández Archipiélago and from Villarrica to Aisen. GLOBAL DISTRIBUTION: australasian.

(Elvebakk et al. 2010).

Xanthoria candelaria (L.) Th. Fr.

Habitat ecology: on rocks in open sites. Records in Aisen: Jeinimeni, Tamango and Laguna San Rafael. Distribution IN Chile: Llanquihue to Isla Navarino and Antarctic Territory. Global Distribution: bipolar.

(Øvstedal \& Lewis Smith 2001; Redón \& Quilhot 1977).

\section{ACKNOWLEDGEMENTS}

We are greatly indebted to D.J. Galloway, J.W. Bjerke, Arve Elvebakk and B. Goffinet for their inestimable collaboration in the identification of the species; to Daniela Castro, Coordinator of the project Biodiversidad de Aisen; to Sergio Herrera, Coordinator of Darwin Project; to CONAF XI Region, especially to Dennis Aldridge and the guardparks Hernán Velázquez, Tomás Ormeño, Javier Subiabre and Benjamín Molina; to Raleigh International and Venturers for field assistance; to Fernanda Cavieres, from the Universidad de Valparaíso, for reviewing the manuscript. We are sincerely grateful to the Dirección de Investigación of the Universidad de Valparaíso for several grants to investigate lichens in Aisen.

\section{REFERENCES}

Adler, M. \& S. Calvelo. 1996a. Noteworthy reports on Anzia (lichenized Ascomycotina) from Southern South America. Mycotaxon 58: 147-156.

Adler, M. \& S. Calvelo. 1996b. Two new species of the genus Menegazzia (Parmeliaceae sensu lato, lichenized Ascomycota) from southern South America. Mycotaxon 59: $367-372$.

Adler, M. \& S. Calvelo. 2002. Parmeliaceae species (lichenized Ascomycetes) from Tierra del Fuego (southern South America) and their world distribution patterns. In: A. Thell $\&$ T. Feuerer (eds.), Biodiversity and Ecology Proceedings of the Fourth Meeting of Latin American Lichenologists. GLAL-4. Mitteilungen aus dem Institut für Allgemeine Botanik, Hamburg 30-32: 9-24.

Анті, T. 2000. Cladoniaceae. Flora Neotropica Monograph 78: 1-
363. New York Bot. Garden, New York.

Arvidsson, L. 1983. A monograph of the lichen genus Coccocarpia. Opera Botanica 67: 1-96.

Arvidsson, L. 1992. Coccocarpiaceae. Flora of Australia 54: 152159.

Arvidsson, L. \& D.J. Galloway. 1981. Degelia, a new lichen genus in the Pannariaceae. Lichenologist 13: 27-50.

BJerke, J.W. 2001. A new sorediate species of Menegazzia (Parmeliaceae, lichenized Ascomycota) from Chile. Lichenologist 33: 117-120.

BJerke, J.W. 2005. Synopsis of the lichen genus Menegazzia (Parmeliaceae, Ascomycota) in South America. Mycotaxon 81: 423-454.

Bjerke, J.W. \& A. Elvebakk. 1999. Flavoparmelia soredians, a common but previously overlooked lichen species in southernmost Chile. Anales Instituto Patagonia, Serie Ciencias Naturales (Chile) 27: 17-23.

BJERKE, J.W.\&A. ElVEBAKK. 2001. The sorediate species of the genus Menegazzia (Parmeliaceae, lichenized Ascomycotina) in southernmost South America. Mycotaxon 78: 363-392.

BJerke, J.W., A. Elvebakk \& W. Quilhot. 2003a. Distribution and habitat ecology of the sorediate species of Menegazzia (Parmeliaceae, lichenized Ascomycota) in Chile. Revista Chilena de Historia Natural 76: 79-98.

Buerke, J.W., D.J. Galloway, A. Elvebakk \& W. Quilhot. 2003b. Pseudocyphellaria dasyphyllidia - a new phyllidiate species from Chile (Lobariaceae, lichenized Ascomycota). Cryptogamie Mycologie 24: 59-66.

Blanco, O., A. Crespo, P.K. Divakar, T.L. Esslinger, D.L. Hawksworth \& H.T. Lumbsch. 2004. Melanelixia and Melanohalea, two new genera segregated from Melanelia (Parmeliaceae) based on molecular and morphological data. Mycological Research 108: 873-884.

Brodo, I.M. \& D.L. Hawksworth. 1977. Alectoria and allied genera in North America. Opera Botanica 42: 1-164.

Brusse, E.A. \& I. Kärnefelt. 1991. The new Southern Hemisphere genus Coelopogon (Lecanorales, Ascomycotina) with a new species from South Africa. Mycotaxon 42: 35-41.

Calvelo, S., E. Stocker-Wörgötter, S. Liberatore \& J.A. Elix. 2003. Protousnea fibrillatae sp. nov. (Parmeliaceae, lichenized Ascomycota) from Argentina, Southern South America. Mycotaxon 80: 277-287.

Calvelo, S., E. Stocker-Wörgötter, S. Liberatore \& J.A. Elix. 2005. Protousnea (Parmeliaceae, Ascomycota) a genus endemic to southern South America. Bryologist 108: 1-15.

Crespo, A. \& L.G. Sancho. 1978. Umbilicariaceae (Lichenes) de la Sierra de Guadarrama (España). Anales Intituto Botánica Cavanilles 85: 79-101.

Culberson, W.L. \& C.F. Culberson. 1968. The lichen genera Cetrelia and Platismatia (Parmeliaceae). Contribution to the U.S. National Herbarium 34: 449-558.

Daniels, L.D. \& T.T. Veblen. 2000. ENSO effects on temperature and precipitation of the Patagonian-Andean region: implications for biogeography. Physical Geography 21: 223-252.

Elix, J.A. 1992. Hypogymnia. Flora of Australia 54: 201-213.

Elix, J.A. 1994. Hypotrachyna. Flora of Australia 55: 49-59.

Elix, J.A. \& P.M. McCARthy. 1998. Catalogue of the lichens of the smaller Pacific Islands. Bibliotheca Lichenologica 70; pp. 1-361. J. Cramer, Berlin, Stuttgart. 
Elvebakk, A. 2007. The panaustral lichen Pannaria sphinctrina (Mont.) Tuck. and the related new species $P$. lobulifera from New Caledonia. Cryptogamie, Mycologie 28: 225235

Elvebakk, A. \& J.W. BJerke. 2005. Pannaria isabellina (Vain.) comb. nov., a remarkable lichen species from Chile. Lichenologist 37: 47-54.

Elvebakk, A. \& R. Moberg. 2002. Foliose and placodioid species of the lichen family Physciaceae in southernmost Chile. Lichenologist 34: 311-320.

Elvebakk, A., J. Fritt-Rasmussen \& J.A. Elix. 2007. The New Zealand lichen Pannaria leproloma (Nyl.) P.M. Jørg. and its panaustral relative $P$. farinosa nom. nov. Lichenologist 39: 349-359.

Elvebakk, A., E.H. Robertsen, Ch.H. Park \& S.G. Hong. 2010. Psorophorus and Xanthopsoroma, two new genera for yellow-green, corticolous and squamulose lichen species, previously in Psoroma. Lichenologist 42: 563-585.

Fedorenko, N., S. Stenroos, A. Thell, T.I. Kärnefelt \& S.Y. KoDRATYUK. 2009. A phylogenetic analysis of xanthorioid lichens (Teloschistaceae, Ascomycota) based on ITS and mtSSU sequences. Bibliotheca Lichenologica 100: 49-94.

Filson, R.B. 1992. Collema. Flora of Australia 54: 161-173.

Follmann, G. 1967. Die Flechtenflora der nordchilenischen Nebeloase Cerro Moreno. Nova Hedwigia 14: 215-281.

Fos, S. \& P. ClerC. 2000. The lichen genus Usnea on Quercus suber in Iberian cork-oak forests. Lichenologist 32: 6788.

Galloway, D.J. 1983. New taxa in the New Zealand lichen flora. New Zealand Journal of Botany 21: 191-199.

Galloway, D.J. 1985. Flora of New Zealand Lichens. P.D. Hasselberg, Government Printer, Wellington, New Zealand. pp. 1-662.

Galloway, D.J. 1992a. Lichens of Laguna San Rafael, Parque Nacional "Laguna San Rafael”, southern Chile, indicators of environmental change. Global Geology and Biogeography Letters 2: 37-45.

Galloway, D.J. 1992b. Studies in Pseudocyphellaria (lichens) III. The South American species. Bibliotheca Lichenologica 46: $1-275$.

GALlOWAY, D.J. 1994. Studies on the lichen genus Sticta (Schrreber) Ach. I. Southern South American species. Lichenologist 26: 223-282.

Galloway, D.J. 1996. Los líquenes del bosque templado de Chile. In: J.J. Armesto, C. Villagrán, M.K. Arroyo (eds.). Ecología de los bosques nativos de Chile; pp. 101-112. Editorial Universitaria, Universidad de Chile.

Galloway, D.J. 1998. The lichens of Chile: present knowledge and future prospects. In: M.P. Marcelli \& M.R.S. Seaward (eds.). Lichenology in Latin America: history, current knowledge and applications; pp. 87-100. CETEBS. Sao Paulo.

Galloway, D.J. 2002. Taxonomic notes on the lichen genus Placopsis (Argyriaceae, Ascomycotina) in southern South America with a key to species. In: A. Thell \& T. Feuerer (eds.), Biodiversity and Ecology. Proceedings of the fourth Meeting of Latin American Lichenologists. GLAL-4. Mitteilungen aus dem Institut für Allgemeine Botanik, Hamburg 30-32: 79-107.

GallowaY, D.J. 2006. Notes on the holotype of Sticta damaecornis $\beta$ wiegelii Ach. (= Sticta wiegelii). Lichenologist 38: 8992.

Galloway, D.J. 2007. Flora of New Zealand Lichens. Revised second edition including lichen-forming and lichenicolous fungi. Manaaki Whenua Press. Lincoln. Pp. I2261.

Galloway, D.J. 2010. Additions to the Placopsis mycobiota (Trapeliaceae, Ascomycota), of southern South America, with notes on new records (including Aspiciliopsis macrophthalma), and a revised key regional key to species. Lichenologist 42: 727-737.

Galloway, D.J. \& G. Guzmán Grimaldi. 1988. A new species of Phlyctis from Chile. Lichenologist 20: 393-397.

Galloway, D.J. \& P.W. James. 1985. The lichen genus Psoromidium Stirton. Lichenologist 17: 173-188.

Galloway, D.J. \& P.W. JAMES. 1987. Metus, a new austral lichen genus and notes on an Australasian species of Pycnothelia. Notes from the Royal Botanical Garden Edinburgh 44: 561-570.

Galloway, D.J. \& P.M. Jørgensen. 1987. Studies on the lichen family Pannariaceae. II. The genus Leioderma Nyl. Lichenologist 19: 345-400.

Galloway, D.J. \& P.M. Jørgensen. 1995. The lichen genus Leptogium (Collemataceae) in southern Chile. In: F.J.A. Daniels, M. Schultz \& J. Peine (eds.), Flechten Follmann. Contributions to Lichenology in honour of Gerhard Follmann; pp. 227-247. Geobotanical and Phytotaxonomical Study Group. Botanical Institut, University of Cologne, Cologne, Germany.

Galloway, D.J. \& W. Quilhot. 1999 [1998]. Checklist of Chilean lichen-forming and lichenicolous fungi. Gayana Botanica 55: 111-185.

Galloway, D.J. \& L.A. Watson-Gandy. 1992. Lepolichen coccophorus (Lichenized Ascomycotina, Coccotematraceae) in South America. Bryologist 95: 227232.

Galloway, D.J., W. Quilhot \& P.M. Jørgensen. 2006. Pannaria conoplea and P. tavaresii (Ascomycota: Parmeliaceae) new to Chile. Lichenologist 38 83-87.

Goward, T. \& T. Ahti. 1992. Macrolichens and their zonal distribution in Wells Gray Provincial Park and its vicinity, British Columbia, Canadá. Acta Botanica Fennica 147: 160

Goward, T., B. Goffinet \& O.Vitikainen. 1995. Synopsis of the genus Peltigera (lichenized Ascomycetes) in British Columbia, with a key to the Northamerican species. Canadian Journal of Botany 73: 91-111.

Grube, M \& G. Kantivilas. 2006. Siphula represents a remarkable case of morphological convergence in sterile lichens. Lichenologist 38: 241-249.

HaLe, M.E. JR. 1974. Delimitation of the lichen genus Hypotrachyna (Vain.) Hale. Phytologia 28: 340-342.

Hale, M.E. JR. 1975. A revision of the lichen genus Hypotrachyna (Parmeliaceae) in tropical America. Smithsonian Contributions Botany 25:1-73.

Halonen, P., L. Myllys, S. Velmala \& H. Hyvärinen. 2009. Gowardia (Parmeliaceae) - a new alectorioid lichen genus with two species. Bryologist 112: 138-146.

Henssen, A. \& B. Renner. 1981. Studies on the genus Psoroma. 2. Psoroma tenue and Psoroma cinnamomeum. Mycotaxon 13: 433-440. 
Gayana Bot. 69(1), 2012

Hertel, H. 1997. On the genus Lecidea (Lecanorales) in Southern Chile and Argentina. In: L. Tibell. \& I. Hedberg (eds.), Lichen Studies Dedicated to Rolf Santesson. Symbolae Botanicae Upsalienses, Acta Universitatis Upsaliensis 32: 95-111.

Hertel, H. 2001. Floristic and taxonomic notes on saxicolous lecideoid lichens. Sendtnera 7: 93-136.

Hertel, H. 2007. Notes on and records of Southern Hemisphere lecideoid lichens. In: I. Kärnefelt \& A. Thell (eds.) Lichenological Contributions in Honour of David Galloway, Bibliotheca Lichenologica 95: 267-296. J. Cramer Berlin-Stuttgart.

Högberg, N., S. Kroken, G. Thor \& J.W Taylor. 2002. Reproductive mode and genetic variation suggest a North American origin of European Letharia vulpina. Molecular Ecology 11: 1191-1196.

JACOBSEN, P. \& L. KAPPEN. 1989. Notes on Rinodina olivaceobrunnea in the Antarctic. Lichenologist 21: 173-177.

James, P.W. \& F.J. White. 1987. Studies on the genus Nephroma I. The European Macaronesian species. Lichenologist 19: 215-268.

Jørgensen, P.M. 1999. Studies in the lichen family Pannariaceae VIII. Seven new parmelielloid lichens from New Zealand. New Zealand Journal of Botany 37: 257-268.

Jørgensen, P.M. 2004. Further contributions to the Pannariaceae (lichenized Ascomycetes) of the Southern Hemisphere. Bibliotheca Lichenologica 31: 341-347.

Jørgensen, P.M. 2006. Conspectus familiae Pannariaceae (Ascomycetes lichenosae). Revised version. Botanisk Institutt, Bergen University. Norway. Pp. 1-84.

Jørgensen, P.M. \& D.J. Galloway. 1992. Pannariaceae. Flora of Australia 54: 246-293.

Jørgensen, P.M. \& M. Wedin. 1999. On Psoroma species from the Southern Hemisphere with cephalodia producing vegetative dispersal units. Lichenologist 31: 341-347.

Kantvilas, G. 1986. Studies on the lichen genus Siphula in Tasmania I. Siphula complanata and its allies. Herzogia 15: $1-12$.

Kantvilas, G. \& J.A. Elix. 2002. The taxonomy, chemistry and morphology of some South American species of Siphula. Herzogia 15: 1-12.

Kärnefelt, I., J.E. Mattsson \& A. Thell. 1992. Evolution and phylogeny of cetraroid lichens. Plant Systematics and Evolution 183: 113-160.

KitzBerger, T. \& T.T. Veblen. 2000. Effects of climatic variability on facilitation of tree establishment in northern Patagonia. Ecology 81: 1914-1924.

Krog, H. 1976. Lethariella and Protousnea, two new lichen genera in Parmeliaceae. Norwegian Journal of Botany 23:83-106.

Kümmerling, H., D. Triebel \& G. Rambold 1993. Lepraria neglecta and its lichenicolous fungi. Bibliotheca Lichenologica 53: 147-160.

LAMB, I.M. 1977. A conspectus of the lichen genus Stereocaulon (Schreb.) Hoffm. Journal of the Hattori Botanical Laboratory 44: 209-250.

LAUNDON, J.R. 1981. The species of Chrysothrix. Lichenologist 13: 101-121.

Louwhoff, S.H.J.J. \& J.A. Elix. 2002. The Parmeliaceae (lichenized Ascomycota) of New Caledonia. Lichenologist 34: 373-394.
LÜCKING, R. 1992. Foliicolous lichens. A contribution to the knowledge of the lichen flora of Costa Rica, Central America. Nova Hedwigia 104: 1-179.

LÜCKING, R. \& K. KalB. 2000. Foliikole Flechten aus Brasilien (vornehmlich Amazonien), inklusive einer Checkliste und Bemerkungen $\mathrm{zu}$ Coenogonium und Dimerella (Gyalectaceae). Botanische Jahrbücher 122: 1-61.

LÜcking, R., V. Wirth, L.I. Ferraro \& M.S.C. Cáceres. 2003. Foliicolous lichens from Valdivian temperate rainforest of Chile and Argentina: evidence of an austral element, with the description of seven new taxa. Global Ecology and Biogeography 12: 21-36.

Lumbsh, H.T. \& J.A. Elix. 2004. Lecanora. Flora of Australia $56 \mathrm{~A}: 12-62$.

MacCune, B. 2002. Hypogymnia. In: T.H. Nash III, B.D. Ryan, C. Gries \& F. Bungartz (eds.), Lichen Flora of the Sonoran Desert Region Vol. 1: 228-238. Lichens Unlimited, Arizona State University, Tempe, Arizona.

Martínez, I., A.R. Burgaz, O. Vitikainen \& A. Escudero. 2003. Distribution patterns in the genus Peltigera Willd. Lichenologist 35: 301-323.

Messuti, M.I. 1996. Notes on the lichen genus Coccotrema in southern South America. New Zealand Journal of Botany 34: $57-64$

Messuti, M.I. 2005. The genus Pertusaria (Pertusariales: Pertusariaceae) in the Juan Fernandez Archipiélago. 2005. Lichenologist 37: 111-122.

Messuti, M.I. \& P.L. Codesal. 2009. Phaeographis patagonica (Graphidaceae, Ascomycota), nueva cita para Argentina. Gayana Botanica 66: 301-303.

Messuti, M.I., G. Vobis \& I.N. De La Rosa. 2007. First record of the lichen Metus pileatus in Argentina In. I. Kärnefelt \& A. Thell (eds.) Lichenological Contributions in Honour of David Galloway, Bibliotheca Lichenologica 95: 471-477. J. Cramer Berlin-Stuttgart.

Muñoz-Schick, M., R. Pinto, A. Meza \& A. Moreira-Muñoz. 2001. "Oasis de neblina" en los cerros costeros del sur de Iquique, Región de Tarapacá, Chile, durante el evento El Niño 1997-98. Revista Chilena de Historia Natural 74: 389-405.

NASH III, T.H. \& J.A. Elix. 2002a. Flavoparmelia. In: T.H. Nash III, B.D. Ryan, C. Gries \& F. Bungartz (eds.), Lichen Flora of the Sonoran Desert Region Vol. 1: 194-196. Lichens Unlimited, Arizona State University, Tempe, Arizona.

NASH III, T.H. \& J.A. Elix. 2002b. Parmotrema. In: T.H. Nash III, B.D. Ryan, C. Gries \& F. Bungartz (eds.), Lichen Flora of the Sonoran Desert Region Vol. 1: 316-339. Lichens Unlimited, Arizona State University, Tempe, Arizona.

Nash III, T.H. \& J.A. Elix. 2002c. Rimelia. In: T.H. Nash III, B.D. Ryan, C. Gries \& F. Bungartz (eds.), Lichen Flora of the Sonoran Desert Region Vol. 1: 449-451. Lichens Unlimited, Arizona State University, Tempe, Arizona.

Nash III, T.H., Gries, C. \& J.A. Elix. 1995. A revision of the lichen genus Xanthoparmelia in South America. Biblioth. Lichenol. 56: 1-157.

Nash III, T.H., H.G.M. Sipman \& J.A. Elix. 2002. Hypotrachyna. In: T.H. Nash III, B.D. Ryan, C. Gries \& F. Bungartz (eds.), Lichen Flora of the Sonoran Desert Region Vol. 1:238-251. Lichens Unlimited, Arizona State University, Tempe, Arizona. 
Øvstedal, D.O. \& R.I. Lewis Smith. 2001. Lichens of Antarctica and South Georgia. A Guide to their Identification and Ecology. Cambridge University Press.

Parmasto, E. 1978. The genus Dictyonema (Thelephorolichenes). Nova Hedwigia 29: 99-144.

Passo, A. \& S. Calvelo. 2006. New reports and combinations in de family Pannariaceae (Lecanorales, lichenized Ascomycota). Lichenologist 38: 549-555.

Passo, A., S. Stenroos \& S. Calvelo. 2008. Jorgensenia, a new genus to accommodate Psoroma cephalodium (lichenized Ascomycota). Mycological Research 112:1455-1474.

Printzen, C., S. Ekman \& T. Tønsberg. 2003. Phylogeography of Cavernularia hultenii: evidence of slow genetic drift in a widely disjunct lichen. Molecular Ecology 12: 14731486.

Quilhot, W., C. Rubio \& J.W. BJerke. 2002a. El género Menegazzia (Parmeliaceae, Ascomycotina liquenizada) en Laguna San Rafael, sur de Chile. Boletín Museo Nacional Historia Natural Chile 51: 81-84.

Quilhot, W., C. Rubio, M. Bernal \& M. Wedin. 2002b. Estructura de comunidades liquénicas en troncos basales de Embothrium coccineum en Laguna San Rafael, sur de Chile. Boletín Museo Nacional Historia Natural Chile 51: 85-96.

Quilhot, W., C. Rubio, E. Fernández \& M.E. Hidalgo. 2002c. Efectos de la radiación UV-solar en la acumulación de 1 '-cloropanarina en Erioderma leylandii (Pannariaceae, Ascomycotina liquenizado) en Laguna San Rafael, sur de Chile. Boletín Museo Nacional Historia Natural Chile 51: 75-80.

Quilhot W., C. Rubio \& M. Cuellar. 2007. Comparative studies between the lichen flora from Chile and Antarctica. In: I. Kärnefelt \& A. Thell (eds.), Lichenological Contributions in Honour of David Galloway. Bibliotheca Lichenologica Band 95, pp. 479-488.

Quilhot, W., M. Cuellar, R. Díaz, F. Riquelme \& C. Rubio. 2010. Estudio preliminar de la flora liquénica de Isla Mocha, sur de Chile. Gayana Botanica 67: 194-200.

Rambold, G. 1989. Amonograph of the saxicolous lecideoid lichens of Australia (excl. Tasmania). Bibliotheca Lichenologica 34: 1-345.

Redón, J. 1974. Observaciones sistemáticas y ecológicas en líquenes del Parque Nacional Vicente Pérez Rosales. Anales del Museo de Historia Natural de Valparaíso 7: 169-222.

Redón, J. 1985. Líquenes Antárticos. Instituto Antártico Chileno, INACH, Santiago.

Redón J \& W. Quilhot. 1977. Los líquenes de Isla Navarino. I. Estudio sistemático y ecológico preliminar. Serie Científica Instituto Antártico Chileno 5: 65-70.

Redón J. \& A. WalkowiaK. 1978. Estudio preliminar de la flora liquénica del Parque Nacional "La Campana". I. Resultados sistemáticos. Anales del Museo de Historia Natural de Valparaíso 11: 19-36.

Ryan, B.D. 2002a. Bryoria. In: T.H. Nash III, B.D. Ryan, C. Gries \& F. Bungartz (eds.), Lichen Flora of the Sonoran Desert Region Vol. 1: 109-114. Lichens Unlimited, Arizona State University, Tempe, Arizona.

Ryan, B.D. 2002b. Parmeliopsis. In T.H. Nash III, B.D. Ryan, C.
Gries \& F. Bungartz (eds.), Lichen Flora of the Sonoran Desert Region Vol. 1: 315-317. Lichens Unlimited, Arizona State University, Tempe, Arizona.

Ryan, B.D. 2002c. Rhizoplaca. In: T.H. Nash III, B.D. Ryan, C. Gries \& F. Bungartz (eds.), Lichen Flora of the Sonoran Desert Region Vol. 1: 442-448. Lichens Unlimited, Arizona State University, Tempe, Arizona.

Sancho, L.G., L. Kappen \& B. Schroeter. 1992. The lichen genus Umbilicaria on Livingston Island, South Shetland Islands, Antarctica. Antarctic Science 4: 189-196.

ScheidegGer, D. 1993. A revision of saxicolous species of the genus Buellia De Not. And formerly included genera in Euorope. Lichenologist 25: 315-364.

Schmitt, I., M.I. Messuti, G.B. Geige \& H.T. Lumbsch. 2001. Molecular data support rejection of the generic concept in the Coccotremataceae (Ascomycota). Lichenologist 33: 315-321.

Sipman, H.J.M. 1986. Notes on the lichen genus Everniastrum (Parmeliaceae). Mycotaxon 26: 235-251.

Stenroos. S. 1995. Cladoniaceae (Lecanorales. Lichenized Ascomycotina) en la flora de Chile. Gayana Botanica 52: 89-131.

Timdal, E. 2002. Toninia . In: T.H. Nash III, B.D. Ryan, C. Gries \& F. Bungartz (eds.), Lichen Flora of the Sonoran Desert Region Vol. 1, pp. 488-502. Lichens Unlimited, Arizona State University, Tempe, Arizona.

Timdal, E. \& T. Tønsberg. 2006. Psoroma palaceum comb. nov. The only hairy Psoroma in Northern Europa. Graphis Scripta 18: 54-57.

UACH-UDEC. 2007. Determinación de las líneas de base de vegetación y flora terrestre para el Proyecto Hidroeléctrico Aysén. Informe de manejo forestal. UACH-Instituto de Botánica, Universidad de Concepción. 235 pp.

UACH-UDEC. 2008. Determinación de las líneas de base de vegetación y flora terrestre para el Proyecto Hidroeléctrico Aysén. Informe Complementario. Instituto de Manejo Forestal UACH- Instituto de Botánica, Universidad de Concepción. 43 pp.

Villagra, J., D. Montenegro, C. San Martín, C. Ramírez \& I. Alvarez. 2009. Estudio de la flora liquénica de las turberas de la comuna de Tortel (Región de Aisen) Patagonia Chilena. Anales del Instituto de la Patagonia, Universidad de Magallanes, Chile 37: 53-62.

Wedin, M. 1995. The lichen family Sphaerophoraceae (Caliciales, Ascomycotina) in temperate areas of the Southern Hemisphere. Symbolae Botanicae Upsalienses 31: 1-102.

Wedin, M. 2002. The genus Calycidium Stirt. Lichenologist 34: 63-69.

White, F.J. \& P.W. James. 1988. Studies on the genus Nephroma II*, the southern temperate species. Lichenologist 20: 103166.

Wirtz, N. 2006. Phylogenie und phylogeographie antarktischer und bipolar flechten der Gattung Usnea and Neuropogon. Dissertation, University Duisburg-Essen, Germany.

Wirtz, N., C. Printzen \& H.t. Lumbsch. 2008. The delimitation of Antarctic and bipolar species of neuropogonoid Usnea (Ascomycota, Lecanorales): a cohesion approach of species recognition for the Usnea perpusilla complex. British Mycological Society 112: 472-484.

Recibido: 21.06.11

Aceptado: 12.10.11 